A thematic paper supporting the OECD DAC INCAF project

'Global Factors Influencing the Risk of Conflict and Fragility'

\title{
The power of radical Islamist ideas in fragile states in parts of sub-Saharan Africa
}

Abdelkérim Ousman

Royal Military College of Canada
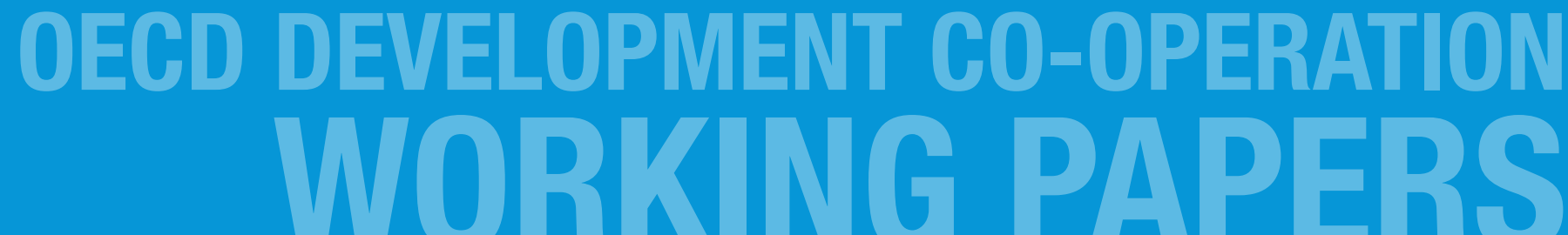

The Development Assistance Committee: Enabling effective development 
This work is published on the responsibility of the Secretary-General of the Organisation for Economic Cooperation and Development (OECD). The opinions expressed and arguments employed herein do not necessarily reflect the official views of the Organisation or of the governments of its member countries.

This document and any map included herein are without prejudice to the status of or sovereignty over any territory, to the delimitation of international frontiers and boundaries and to the name of any territory, city or area.

\section{Note to the reader}

This paper is one of eight thematic papers supporting the OECD DAC INCAF project on Global Factors Influencing the Risk of Conflict and Fragility. Each paper explores a specific global factor. The synthesis report, Think Global, Act Global: Confronting global factors influencing conflict and fragility (OECD, 2012), can be found at:

\section{www.oecd.org/dac/conflictandfragility/globalfactors.htm}

While the thematic papers have been subjected to a robust peer review process, they remain working papers rather than for publication in peer-reviewed journals. 


\section{Abstract}

In parts of sub-Saharan Africa, radical Islamists are targeting fragile and conflict-affected states and encouraging the formation of groups which act against the state (either violently or subversively). These processes exacerbate existing fragility and increase conflicts among communities in countries that already suffer from poor social cohesion and integration. This paper describes the ideas and methods with which radical Islamist groups are destabilising some fragile and conflict-affected states in sub-Saharan Africa, such as Sudan, Nigeria and Chad. It also evaluates the extent to which modern communication technologies help spread these ideas among Islamists in these states. In supporting fragile and conflictaffected states that are being infiltrated by radical Islamism, international donors should tackle two related phenomena:

1) regulating the telecommunication market and use of the Internet and social media; and

2) improving education. The non-violent aspects of Islamist radicalisation processes suggest that a dialogue with radical Islamists is still possible. In this sense, some of their projects, particularly their efforts at Arabisation, could be harnessed to increase literacy levels in order to favour general education and development and diminish fragility. 


\section{Table of Contents}

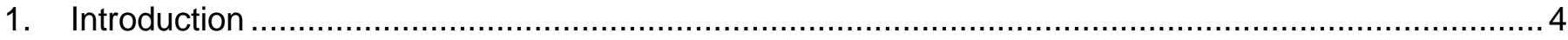

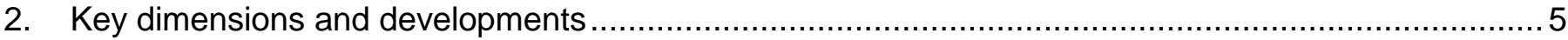

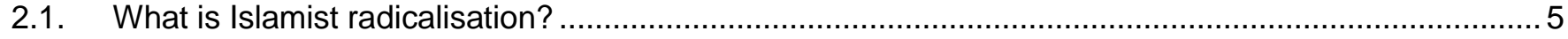

2.2. What is driving the Islamisation and Arabisation processes in parts of sub-Saharan Africa? ............... 7

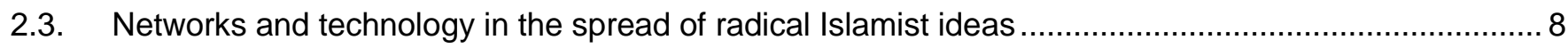

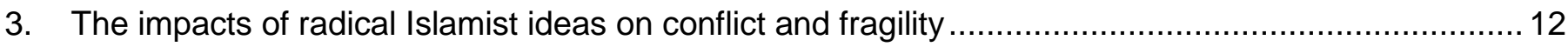

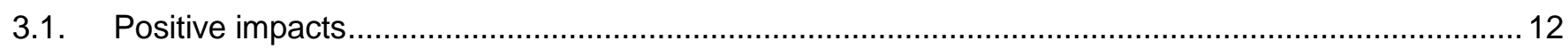

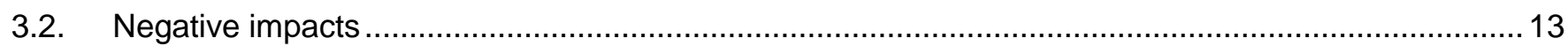

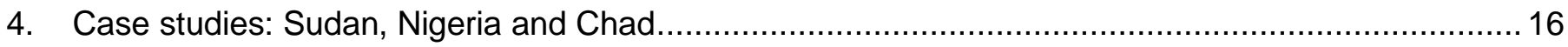

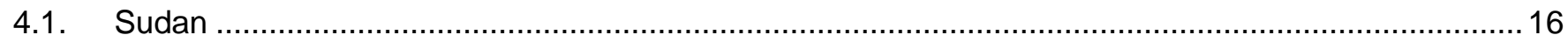

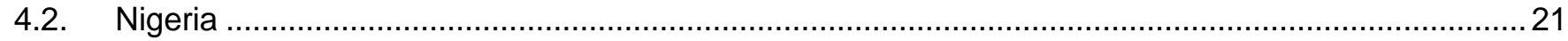

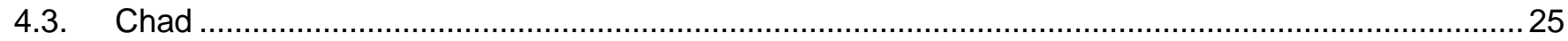

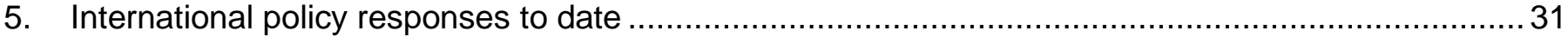

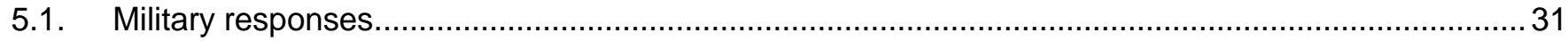

5.2. Social, economic and political responses ………

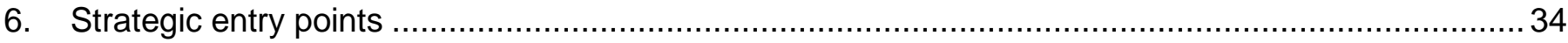

6.1. Regulating the telecommunication market, the use of Internet and social media ……......................... 34

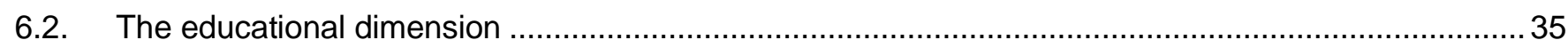

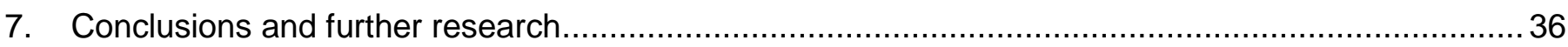

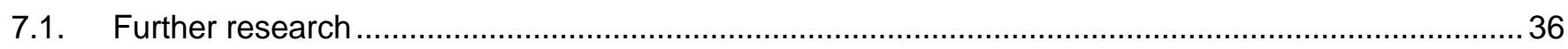

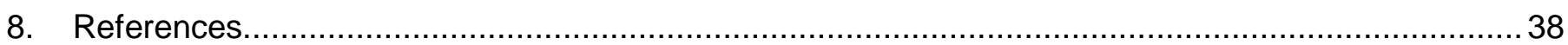

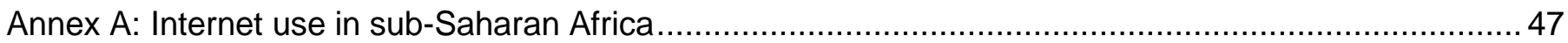

\section{Boxes}

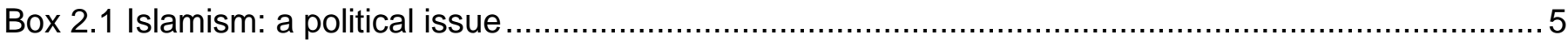

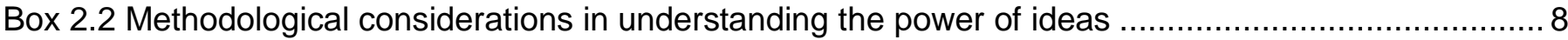

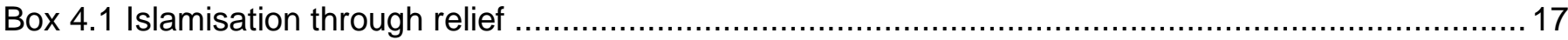




\title{
1. Introduction
}

To propagate their version of Islam, radical Islamists are targeting fragile and conflict-affected states' in parts of sub-Saharan Africa, where they motivate "exit movements" from state control among African Muslim communities. These exit movements are "mostly anti-system, mostly grassroots... with a variety of political social and economic goals ... which are often beyond the control of the state" (Haynes, 1997). Radical Islamists can encourage the formation of groups which act violently against the state, adding to existing fragility and furthering conflicts among communities in countries that suffer from poor social cohesion and integration. Their political objective is to bypass the state by ideologically driving individuals to dream of economic, political or cultural systems which transcend the state, while submerging the latter with violent movements making unrealistic claims."

The purpose of this paper is to identify the radical Islamist ideas that motivate domestic groups to initiate popular movements in some fragile and conflict-affected states in sub-Saharan Africa, such as Sudan, Nigeria and Chad. This paper is not about Islam in Sub-Saharan African in general, which historically has taken many forms according to different national contexts. In fact, there are as many forms of Islam in Africa as in the rest of the world. Rather, the problem dealt with in this paper is radical Islam, which is a foreign idea that came to Africa from Saudi Arabia to negate diversity in the practice of the religion, among other reasons.

The paper also explores the extent to which modern communication technologies help spread these ideas among Islamists in these states. Furthermore, it will evaluate existing policy responses and make recommendations for the policy community in order to better enable weak and conflict-affected states to counter radical Islamist ideas and shield their Muslim communities from discord among themselves and with other religious communities.

This paper is organised as follows: the next section defines terms such as Islamist, Islamism and radicalisation, and outlines the key dimensions and debates around the issue of radical Islam. The third section assesses both the positive and negative impacts of radical Islamist ideas on conflict and fragility. These are illustrated further in three case studies presented in Section 4: of Sudan, Nigeria and Chad. The fifth section outlines the international policy responses, especially by the United States and the European Union. Section 6 develops some strategic entry points for international actions, before Section 7 concludes with some areas for further research.

\section{NOTES}

\begin{abstract}
' The OECD defines a fragile state as one that has "weak capacity to carry out basic functions of governing a population and its territory, and lacks the ability to develop mutually constructive and reinforcing relations with society. As a consequence, trust and mutual obligations between the state and its citizens have become weak" (OECD, 2011). In many sub-Saharan states, elements of fragility include a narrow social basis for political authority, an exclusive political system limited to a small set of tribal and military interests, and repressive state institutions. Even when democracy exists, it is often limited to rigged electoral processes. These states, in contrast to more resilient ones in other parts of the world, are unable to absorb internal and external shocks.
\end{abstract}

"For more on the exit phenomenon, please see Bayart (1986; 1991). 


\section{Key dimensions and developments}

There are three key dimensions treated in this paper:

1) Islamist radicalisation

2) Arabisation and Islamisation

3) Networks and technology in the service of spreading radical Islamist ideas

\subsection{What is Islamist radicalisation?}

For the sake of clarity and consistency, I use the terms radical Islam and Islamism (Box 2.1) instead of fundamentalism and fundamentalists. This is because radical Islamists are not fundamentalists, despite their claims to the contrary. Their project is political in nature rather than theological. This paper is not about the theological legitimacy of radical Islamist ideas. Rather, it tries to understand the processes through which some Muslims become radicals.

\section{Box 2.1 Islamism: a political issue}

Islamism is another word for "political Islam". Wikipedia describes Islamism as a: "set of ideologies holding that Islam is not only a religion but also a political system; that modern Muslims must return to their roots of their religion, and unite politically. Islamism is a controversial term and definitions of it sometimes vary. Many confuse or conflate Islamism with Salafism, however early Salafism is the contrary to modern Islamism".

The term Salafism refers to those who claim to follow the forefathers of Islam. It is based on the "Ideal of emulating the early fathers as a basis for Islamic renewal first developed by the medieval Hanbali jurist of Damascus, Ibn Taymiyya, and those followed became known as salafiyya - 'followers of the forefathers"' (Allen, 2006: 210). There is no doubt that from its origin Salafism is a form of radical Islam, which justifies its raison d'être by opposing Sufi Islam. These characteristics of Salafism are very well known among Muslims. According to Allen, Ibn Tamiyya "attacked the great Sufi mystic of the age, Ibn al-Arabi, and condemned as polytheistic and heretical many folk practices that have entered the Sunni mainstream". (Allen, 2006: 44).

For details of the Islamist worldview, modus operandi, and actors, see International Crisis Group (2005), "Understanding Islamism", Middle East/North Africa Report N³7, 2 March 2005, http://merln.ndu.edu/archive/icg/Islamism2Mar05.pdf.

\section{What does Islamist radicalisation involve?}

The processes of radicalisation are not unique to the Muslim world. There is a consensus among scholars that "throughout the world, communities are reestablishing, redefining and reinvigorating religions and religious practices. Christianity, Judaism and Hinduism, among others, are also experiencing new surges of commitments to tradition" (AlSayyad and Massoumi, 2012). Scholars do diverge, however, in their opinion of which factors explain the processes of radicalisation. Some scholars argue that these strengthened ties are important means of resistance against hegemonic forces of globalisation, while others interpret the rise of these religious practices as articulating alternative forms of non-Western modernity (AISayyad, 2011). In fact, the Salafi movement (Box 2.1), for example, could be seen as both a 
resistance to globalisation forces and a non-Western form of modernity. Alao (2009) defines radicalisation as a dynamic process formed by a complex interaction of multiple events, actors, relationship, beliefs and institutions. He sees one of the main features of radicalisation as its unconventional approach to religious or political issues: it resorts to behaviour, attitude, values and moral standards which are different to the status quo. For Alao, therefore, radicalisation is also "a phenomenon that operates at multiple levelsindividual (micro), group (meso) and societal (macro). It is a social reality that transcends different spheres of life." (Alao, 2009: 15). Indeed, as noted in a study sponsored by the European Commission (EC):

...radicalization processes can evolve in many directions, including non-violent ones. Radicals can engage in non-violent behavior without terrorist intent that can nevertheless be perceived as radical. For example, radicalization can prompt people to become committed to extreme dawa or missionary practices or intense religious devotion. In some cases these acts forebode terrorist engagement. In others they do not. (EC, 2008a)

The non-violent trends of Islamist radicalisation processes suggest that a dialogue with radical Islamists is still possible. In this sense, some of their projects, particularly their Arabisation efforts, could be harnessed to increase literacy levels in order to favour general education and development and diminish fragility. This positive aspect of radicalisation could form a basis for a dialogue which could help to moderate their unilateral attitude and more aggressive dictates, such as outdated restrictions on women's inherent rights as human beings, and violence and intolerance towards those who do not share specific views.

\section{What beliefs and behaviour do Islamists promote?}

On the one hand Islamist radicalisation is very conservative; on the other it is a reaction to the challenges of modernity, a response that could be transformed to serve the general interest in terms of literacy, education and development. Radical Islamist discourse obliges Muslims to undertake jihad" (peaceful or violent) and to establish Islamic communities, Islamist forms of government and ultimately the Caliphate." These are the "co-ordinative dimensions" of radical Islamist discourse (Box 2.2), which imply cognitive elements about the state of Islam in sub-Saharan Africa and what Islamists intend to do about it. For example, radical Islamists find that the Sufi ${ }^{\mathrm{IV}}$ predominance in Islam is bad, while the widespread use of the Arabic language in Islamic practices in general, and in the Sufi liturgical practices in particular, is good. They aim to use the Arabic language to further Arabisation and their brand of Islamisation (defined and discussed below). In fact, one of the signs of both individuals' and groups' involvement in the process of radicalisation is their rejection of Sufi Islam and adoption of both the Arabic language and Salafi-based form of Islamisation. Moreover, unlike the tolerance towards other religions found in the Qur'an, radical Islamism claims that non-believers are immoral (Langman and Morris, 2012). ${ }^{\vee}$

Paradoxically, however, they combine their medieval social and political views with modernism, using "... modern methods - advanced technology, institutional forms, and instrumental rationality - to transform the political order" (Langman and Morris, 2012). This practice has led many scholars, such as Harvey Glickman, to claim that radical Islamism is nothing more than a political ideology. In fact, radical Islam's ideological nature is betrayed by its "...strategy [that] ranges from violence as a prime tactic to political militancy, to competitive political parties that seek local or national representation in parliaments or local governments." (Glickman, 2011). 


\subsection{What is driving the Islamisation and Arabisation processes in parts of sub-Saharan Africa?}

Islamisation is the process of bringing about "in the world a new society wholeheartedly committed to the teachings of Islam in their totality and striving to abide by those teachings in its government, political, economic and social organizations, its relation with other states, its educational system and moral values and all other aspects of its way of life." (Idris, 1976). The word Arabisation is from the verb to "Arabise". Arabisation is not limited to making a population or a nation adopt the Arabic language. It also means causing a community to adopt Arabic customs, manners, speech and outlook (AlKarouri and Obeid, 2003).

Following Schmidt's definition of discourse (Box 2.2), Arabisation and Islamisation are Salafi responses to the particular context of Islam in sub-Saharan Africa. They are answers to the questions of what is Islam in sub-Saharan Africa, what is good and what is bad about it and what can be done? The answer to the question, "what is Islam in Africa?" is that Islam throughout Africa is predominantly Sufi of several brands, all of which the Salafi consider to be bad (Gellar, 2006; Terdman, 2007a). For them, Sufism is a heresy and perversion in both ideas and practice and ought to be removed (Allen, 2006). However, Salafi find some good in the history of Sufism in Sub-Saharan Africa: the several centuries'-old Sufi usage of the Arabic language for the propagation of their ideas and practices. For the Salafi, the rudimentary form of Arabic, which most African Muslims grasp, could be used as a platform to launch fully-fledged Arabisation programmes to underpin their brand of Islamisation. Salafi are aware that "there is a close relationship between the Arabic language and Islam (also considered by linguistic anthropologists). Arabic is the most fitting language to express Semitic thought, and this thought forms the texture of Islam. All over the Moslem world prayers are recited in Arabic...it is in Arabic that the first [Sufi] mystics transmitted their intimate experience; it is in Arabic that the hadith, or the collection of the tradition of the Prophet, is transmitted." (En Terre d'Islam, 1937). ${ }^{\mathrm{VI}}$

This knowledge of the relationship between the Arabic language and Islam allows for Arabisation and Islamisation to provide the recipes and guidelines for political actions and serves to justify policies and programmes for their implementation. In this depiction, while the co-ordinative form of radical Islamist discourse is made of its substantive contents - such as the obligation to undertake jihad (peaceful or violent) and the duty of establishing Islamic communities, Islamist forms of government and ultimately the Caliphate - its communicative forms are made of normative contents that make Arabisation and Islamisation imperatives: according to the Salafi, to become a good Muslim one needs not only to reject Sufism but also to learn Arabic. This attitude is foreign to African Muslims, who have, so far, managed to associate their native languages with their practices of Islam. 


\section{Box 2.2 Methodological considerations in understanding the power of ideas}

The outstanding methodological challenge is how to grasp the potential of Islamist ideas for shaping political movements. One needs to distinguish between two forms of Islamist discourse: (1) the coordinative form and the way in which it is practised among radical Islamists; and (2) its communicative forms as they are deployed as topics of interactions between leaders and followers.

The term discourse, as defined by Vivian A. Schmidt, encompasses not only the substantive content of ideas but also the interactive processes by which ideas are conveyed. "Discourse is not just ideas or 'text' (what is said) but also context (where, when, how, and why it was said). The term refers not only to structure (what is said, or where and how) but also to agency (who said what to whom)" (Schmidt, 2008). This approach allows us to identify ideas both in terms of their co-ordinative dimensions and their cognitive and normative content.

Source: This methodological discussion is inspired by the work of Vivien A. Schmidt (2008), "Discursive Institutionalism: The Explanatory Power of Ideas and Discourse", Ann. Rev. Polit. Sci. 11:303-326.

Differentiating between the two forms of Islamist discourse is the way to uncover its co-ordinative and strategic goals and how these are implemented, based on the knowledge and perception of the context within which Islamists live. It is not only an attempt to understand the power of persuasion of these ideas, but also to identify the processes through which new political, social and religious values emerge and attempt to displace existing values through violent conflicts or normal political processes. These are causal ideas because their implementation requires guidelines for political actions and serve to justify other policies and programmes, such as the marginalisation of non-Muslims and Muslims who oppose Arabisation and Islamisation. In fragile states this could increase the risk of conflict.

This analysis reveals that the exit movement triggered by radical Islamism has not originated from within communities driven to flee state control. Rather, it is initiated and empowered by impulses from outside the subcontinent. As David McCormack rightly observes, despite the general disenfranchisement and disorder that plagues these societies, it would be a mistake to attribute to internal factors the exit movement which radical Islamism generates and empowers (McCormack, 2005). Radical Islamism is an ideology that delegitimises state institutions, local culture and religious practices, while nourishing the processes of Islamisation and Arabisation of local communities. The ultimate objective is to enlarge the global Muslim community - the umma (Judy, 2011).

\subsection{Networks and technology in the spread of radical Islamist ideas}

The social networks within which the processes of Islamisation and Arabisation take place are created by Islamic scholars who received their Islamic education in the Arab Islamic/Islamic world (e.g. Saudi Arabia, Sudan, Egypt). Upon their return to sub-Saharan Africa they bring with them new connecting possibilities in terms of religious ideologies, the Arabic language or even in terms of information and communication technologies (ICT) (Butter, 2011).

One of the religious ideologies being transferred is the Wahhabi-inspired Salafism, which underpins many of the social networks that link sub-Saharan Muslim societies "to the larger Arab and Islamic world. Some networks have been in place for centuries, allowing others to build on them and extend themselves; others are relatively new created by new information and communication technologies" (Butter, 2011). This analysis is confirmed by Quintan Wiktorowicz, who argues that there is a transnational Salafi movement that connects Muslims in a virtual community through a common approach to Islam. The Salafi movement is the most rapidly expanding Islamic movement and has profound influence on the Islamic practice and ideological orientations of Muslims throughout the world. According to the author, the movement is a 
byproduct of globalisation and symbolises the rapid expansion of transnational, virtual networks that serve as platforms for transnational opinion formation and recruitment into radical movements (Wiktorowicz, 2001).

When the processes of radicalisation take shape in the virtual networks they initially engage individuals who join other individuals in already radicalised groups. According to a report sponsored by the European Commission, "radicalisation is seen as a collective phenomenon - a process of socialisation - which is the result of individual behaviour. It implies that radicalisation of collective entities can only be explained if we understand how individual behaviour emerges" (EC, 2008b). This is why methodological individualism ${ }^{\mathrm{VII}}$ is considered a useful approach for understanding how a community becomes radicalised (see Boudon, 1981; Coleman, 1990).

Several studies have argued that Islamic movements in general have benefited enormously from alternative media, particularly information and communication technologies (ICTs), in their efforts to advance their causes and intervene in local and global public spheres (Anderson, 2003; Bunt, 2003; Hoff, 2005; Ibahrine, 2007; and Kort, 2005). Through analysing websites belonging to Islamist organisations, these studies have explored the impact of online communication and networks on the public sphere and religious discourse. They have specifically examined the role of these websites in reshaping the control of religious and political institutions.

These websites form networks; networking has always been central to social movement organisations in terms of structure and collective action (Diani, 2001; McAdam, 1982). Moreover the networks are generally based on a large and complex web of organisations, groups and individuals. They also enable the formation of alliances among "diverse social actors, including social movement organisations, media and political parties, with whom they share common objectives, causes or ideological background" (Ben Moussa, 2011). The websites feature daily news about Islamist groups and "the Islamic world, analysis and opinion contributions from member activists in addition to text and multimedia content that can be read, viewed or listened to online, or downloaded for offline use and sharing." (ibid.)

Politically and socially, it is predicted that the merger between communication and computing technologies will increase co-operation among various groups across national borders leading to the emergence of technologically savvy groups of people working together (Rheingold, 2002). The effects of these groups can either be destructive - contributing to fragility and conflict - or beneficial, in that they support democracy (Livingston, 2011). This latter effect has been seen in the Arab Spring and other positive social and political developments (Rheingold, 2002). As witnessed by Frank Windeck, "the introduction of the internet and mobile telecommunications in Africa at the beginning of the millennium has significantly altered this communication structure. The original structures have shifted from a "top-down approach" to a polycentric communications system" (Windeck, 2010), which means that no single entity has monopoly over the dissemination and control of political information.

However, in Sub-Saharan Africa the poor distribution of both electrical power grids ${ }^{\text {VIII }}$ and landline telecommunications networks, coupled with the high costs of computing devices and low rates of computer literacy, mean that the Internet still remains a luxury good, of benefit to only a small political and commercial elite (see Annex A for data).

On the other hand, cell phones and Internet-enabled mobile phone devices are making their way throughout the continent. According to Aker and Mbiti, "in 1999 only 10 percent of Africans had mobile phone coverage, primarily in North Africa....and South Africa...By 2008, 60 percent of the population (477 million) could get a signal...By 2012, most villages will have coverage..." (Aker and Mbiti, 2010). Unlike the Internet, the cell phone market has benefited from the lack of landline services. Furthermore, they "... are straightforward to use and the comparably inexpensive handsets needed only to be connected to a power source, such as a car battery." (OpenNet Initiative, 2009). Even with the burgeoning of Internet 
cafés, it is still "considerably easier to purchase a cell phone in Sub-Saharan Africa than it is to set up a fast Internet connection." (ibid.) It has been also noted that:

Online services such as Facebook and Twitter and an active blogger community have made the Internet interactive, facilitating a form of democratic participation that has been hoped for since before the turn of the millennium. The other side of this new development is the merging of web content and cell phone functions into hybrid systems. (ibid.)

In effect, beyond the classic cell phone use of placing calls, other various functions such as SMS, photo, video and chatrooms have emerged to benefit cell phone users. Again, in contrast to the Internet, cell phone users groups are not always the elite or privileged.

\title{
NOTES
}

\begin{abstract}
' Source: Wikipedia "Islamism" http://en.wikipedia.org/wiki/lslamism\#cite note-0, accessed 23 October 2012.
II "Jihad is the Arabic for what can be variously translated as 'struggle' or 'effort', or 'to strive', 'to exert', 'to fight', depending on the context. In the West, the word is generally understood to mean 'holy war', and the terms are given, inaccurately, exclusively military connotations. The Quran does call for 'jihad' as a military struggle on behalf of Islam. But the Quran also refers to jihad as an internal, individual, spiritual struggle toward self-improvement, moral cleansing and intellectual effort. It is said that Prophet Muhammad considered the armed-struggle version of holy war 'the little jihad', but considered the spiritual, individual version of holy war--the war within oneself--as 'the great jihad'" (Source, About.com Middle East Issues, "Glossary: Jihad definition", available at http://middleeast.about.com/od/religionsectarianism/g/me080122a.htm, accessed 12 November 2012).
\end{abstract}

III In fact, nothing in the scriptures (the Qur'an or the tradition of the Prophet) obliges Muslims to return to the Caliphate. With regards to governance, all that is written in the Qur'an is that "your mundane issues..." - which arguably includes the form of government - "...should be solved in a council among yourselves". Thus, shortly before his death, even the Prophet refused to give any indication when asked who should be his replacement among his first companions. In effect, from the theological point of view radical Islam's claims remain debatable at best.

IV "One of the reasons that Islam is so close to the hearts of West African people is because of Sufism. Sufism is a branch of Islamic Knowledge which concentrates on direct experience and the spiritual development of a Muslim. It is this area of knowledge that provides the social framework for Muslim communities in West Africa. This social framework can be seen in the Muslim communities from Senegal to Nigeria." (Source: Seyfettin (2007), "Islam and Sufism in West Africa", Blog entry, 15 November 152007 at http://wasalaam.wordpress.com/2007/11/15/islam-andsufism-in-west-africa/, accessed 12 November 2012; and see Ousman (2004).

${ }^{\vee}$ See also Tibi (1998).

VI "Arabization or Islamization?" (Translated from French), this article was authored by R.C. (the names are not fully spelled, only initials are provided) in En Terre d'Islam, August 1937 and translated and published in The Muslim World, Vol. 27, Issue No.2 1937, pp. 142-146.

VII Methodological individualism is a doctrine that was "... introduced as a methodological precept for the social sciences by Max Weber, most importantly in the first chapter of Economy and Society (1968 [1922]). It amounts to the claim that social phenomena must be explained by showing how they result from individual actions, which in turn must be explained through reference to the intentional states that motivate the individual actors. It involves, in other words, a commitment to the primacy of what Talcott Parsons would later call 'the action frame of reference'....in social-scientific explanation. It is also sometimes described as the claim that explanations of 'macro' social phenomena must be supplied with 'micro' foundations, ones that specify an action-theoretic mechanism..." "Methodological individualism" (Source: Stanford Encyclopedia of Philosophy, 2010; online encyclopedia, available at http://plato.stanford.edu/entries/methodological-individualism/, accessed 12 November 2012). 
VIII According to the OpenNet Initiative, "Only 17 percent of sub-Saharan Africans have electricity access; in rural areas this drops to 5 percent. Areas that are connected to power grids often suffer outages, and power shortages have forced many countries to operate under load shedding agreements, or rolling blackouts, in which residents receive electricity on a schedule that ranges from every other day to once a week or less"; see OpenNet Initiative "Internet Filtering in Sub-Saharan Africa" 2009, downloaded on March 6, 2012, from http://opennet.net/sites/opennet.net/files/ONI SSAfrica 2009.pdf. 


\section{The impacts of radical Islamist ideas on conflict and fragility}

The impacts of radical Islamist ideas can be both positive and negative, and can be felt in the areas of governance, educational, literacy and development. In these areas, while Islamists promote community self-reliance, at the same time their actions accelerate the exit phenomenon that de-legitimises state institutions. This is due to the fact that their actions - whether they are educational or developmental - are part of the radicalisation, Arabisation and Islamisation processes. The crucial policy question that arises is whether Arabisation and to a lesser extent Islamisation can be harnessed or tamed for the benefit of the general interest in sub-Saharan countries? Before answering this question, one needs to understand the positive and negative effects and impacts of the radicalisation processes.

\subsection{Positive impacts}

\section{Governance}

In terms of governance, in some sub-Saharan states national integration is still problematic and remains one of the main factors behind fragility and conflict (Deegan, 1995). While radical groups such as Boko Haram in Nigeria (see Section 4) and Ansar Dine in Mali reject the Western form of democracy and rule of law as foreign influences, other Islamists in Sudan, Nigeria and Chad think they can win in fair and free electoral processes. This is why Deegan (1995) suggests that both Western and Islamic influences are part of many African countries' historical and cultural heritage. The question is not whether to reject the Western political system and adopt an Islamic one. For the majority of Muslim-populated countries - like Sudan, Northern Nigerian states and to a lesser extent Chad - a combination of Western-based rules of law and a Shari'a-inspired constitutional framework might be preferable to the exclusion of citizens from political participation, since such exclusion is one of the major elements of fragility that leads to conflict (as already experienced by Turkey).

\section{Education}

As discussed earlier, radical Islamism is on the one hand very conservative, while on the other it is a response to the challenges of modernity. Thus some radical Islamists promote the education of women and others who have no access to formal education (Kane, 2003; Loimeir, 1997). Uzma Anzar believes that Islamic education can be used or modified to bring about much-needed social and societal change in the Muslim world. According to him, the first place to begin is the basic literacy level. "In countries where large Muslim populations either do not have access to schools or do not want to send their children, especially girls, to schools, imparting literacy through Koranic schools would be a good start" (Anzar, 2003). In Sierra Leone, for example, high birth rates combined with the limited government resources for general education mean that Islamist educational initiatives could be harnessed in partnership with governmental educational institutions to reinforce the country's educational capacity (Jalloh, 1997).

\section{Social and economic development}

Radical Islam also has some positive impacts on social and economic development. In fact, Islamists can mediate change in egalitarian ways. According to Marc-Antoine Pérouse de Montclos: "A spatial and social reading confirms their modernity, as their ideology appeals to urban migrants, for whom it is easier to renounce traditional loyalties" (Pérouse de Montclos, 2008). Tribalism is one of the problems hindering government legitimacy in many fragile states. The positive impacts and effects of radical Islam are also felt in some development assistance to sub-Saharan countries. The Kingdom of Saudi Arabia, for example, provides considerable official assistance to African communities in the name of Islam and Islamisation: "An example of a channel for such assistance is the Saudi Fund for Development (SFD) that commenced in 1974-established to support development project and programs primarily in Africa and Asia...this 
assistance, while not explicitly designated as propagation activity, is part of the Islamization process." (McCormack, 2005: 6).

\section{2. $\quad$ Negative impacts}

For radical Islamists, one of the domains within which the advent of the Caliphate should be prepared is the intellectual and educational sector. The ultimate aim is to establish Islamist governments in predominantly Muslim geographic areas. This tactic has led organisations such as Ahlus Sunna Wa'al Jama'at (Bryson, undated), the Islamic Development Bank' and the Saudi Princess Nourah University (The Voice of the Cape Radio, 2012) to encourage the enrollment of African students in Islamic education in universities in Africa" (especially Egypt, the Kingdom of Saudi Arabia and Sudan - particularly the Omdurman Islamic University in Sudan): "These universities' overt mission is to train African scholars in creed and branches of Shari'a so that they may carry the message of Islam and teach Islamic subjects" and to spread Salafist and Wahhabi education among pupils and students at different stages of general education. They also groom distinguished students so that they may become members of staff of various national universities, and hence themselves take part in spreading and developing radical Islamic thoughts in different fields of education.

This intellectual and educational effort is accompanied by aggressive policies to transform the government and public sectors into Islamist networks. The idea is to create transmission belts for radical Islamist social policies developed by organisations outside sub-Saharan Africa which rely on trans-African Muslim organisations (subsidiaries of the Organization of the Islamic Conference, now known as the Organization of Islamic Cooperation). In 1974, the conference of World Islamic Organization in Mecca adopted a programme which recommended that:

- Muslim organisations should set up centres to resist Christian missionary activities.

- Islamic radio and TV stations should be established.

- All Christian activities, no matter how secular their expression, should be stopped.

- Christian hospitals, orphanages, schools and universities should be taken over.

- Muslim organisations should set up intelligence centres on Christian activities.

- All Christian literature should be banned in Muslim countries. ${ }^{\text {IV }}$

According to Younoussa Djao, in sub-Saharan countries with Muslim dominance these ideas have been implemented since the 1970s. In some countries, like Nigeria before the ending of military dictatorship, "many streets bearing Christian names were changed to Muslim names. Christian schools and hospitals were taken over by the state. Arabic inscriptions and emblems began to appear on currency notes and on emblems of the country" (Djao, 2006).

The conference recommendations were reiterated in November 1989 during a conference of the Islam in Africa Organization held in Abuja, Nigeria. Participants (representatives from African Muslim countries) agreed to (cited in Djao, 2006):

- support the establishment and application of Shari'a law;

- ensure the appointment of only Muslims into strategic national and international posts of member nations;

- eradicate in all its forms and ramifications all non-Muslim religions in member nations (such religions shall include Christianity);

- ensure that only Muslims are elected to political posts of all member nations;

- ensure the ultimate replacement of all Western forms of legal and judicial systems with the Shari'a in all member nations; 
- write the history of Islam in Africa and of Muslims and their institutions from an authentic Islamic viewpoint;

- $\quad$ propagate the knowledge of Islam throughout the continent;

- call on Muslims to review the syllabi in the various educational institutions with a view to bringing them into conformity with Islamic ideals, goals and principles and to serve the needs of their community;

- encourage the teaching of the Arabic language, which is the language of the Qur'an as well as the lingua-franca of the continent, and to strive for the restoration of the use of Arabic...

- establish strong economic ties between African Islamic countries and other parts of the Muslim world in order to facilitate mutual assistance and co-operation ... based on Islamic principles.

The timing of this conference coincided with the arrival of al-Bashir and al-Turabi in power in Sudan in 1989 , which suggests a possible connection between these recommendations and al-Turabi, the spiritual leader of Islamism in Sudan (see Sudan case study in Section 4). In any case, they are relatively new communicative forms of the Islamist discourse, the impacts of which continue to reverberate throughout some parts of the continent. They contain three issues of concern for international donors:

1. the application of Shari'a law in countries that have secular constitutions;

2. the call for the marginalisation of non-Muslims;

3. the teaching of Arabic to carry messages which penetrate into legitimate state-controlled education and training establishments.

If we take northern Nigeria, where these policies have resonated, the implementation of Shari'a is in fact a call for the marginalisation of Christians and animists. Communicated in this fashion, radical Islamist discourse could have the effect of awakening the demons of violent secession long forgotten since the Biafra war.

In Chad, furthermore, a secession war by the south could be initiated after more than 20 years of marginalisation and oppression of the southern Christians by the Muslim-dominated government. There is a great risk of southern Chadians mimicking the process that led the Southern Sudanese to separate from the rest of Sudan. As will be shown in the case studies in the next section, these policies have already generated judicial activism from radical Chadian Islamists who have expressed the desire to change the Chadian constitution so as to be governed by Islamic laws. There is no doubt that the judicial and political activism generated by these policies will exacerbate fragility and conflict in both countries. 


\section{NOTES}

'See the Islamic Development Bank webpage: "IDB Scholarships for Muslims in Africa and Asia"
www.scholars4dev.com/3729/idb-scholarships-for-muslims/, accessed 12 March 2012.

"There are 17 Islamic universities in Africa. See Megan Lindow, "Islamic Universities Spread Through Africa", http://meganlindow.wordpress.com/articles/is/amic-universities-spread/, July $6^{\text {th }}, 2007$.

IIISee the Department of Guidance and Islamic Education of the Omdurman Islamic University, www-

3.unipv.it/webarchaf/Comboniani/college/storgen/omdurman islamic university.htm

IV Frontline Followship website, "Resisting Shari'a in Nigeria", http://frontline.org.za/index.php?option=com content\&view=article\&id=825:resisting-sharia-innigeria\&catid=27:islam-cat\&ltemid=196, accessed 12 November 2012. 


\section{Case studies: Sudan, Nigeria and Chad}

Sudan has been chosen as the first case study because it is already an Islamist state and has been under Arab hegemony - both ethnically and linguistically - since its independence in 1956. In fact, the policies of Islamist education - grooming Muslims to become influential in strategic positions within the government, and in the economic and financial sectors - were first tested in Sudan. Therefore, the country's experience with radical Islamist ideas is a template for Islamists in both Chad and Nigeria. Indeed the Chad case study demonstrates that Sudan is the main entry point for Islamist ideas in sub-Saharan Africa.

Nigeria represents a process of Islamist radicalisation in a middle-income federal state where radical Islamist ideas are flourishing unchecked.

The case of Chad shows the process of Islamic radicalisation in a low-income and unitary state where even though the advent of modern communication and computer technologies is still in its infancy, they nevertheless have potential for empowering radical Islamist ideas. This is because historically Islamists imported radical Islamist discourse into the country using audio tapes. With the recent arrival of fibre optic in the country and the lack of telecommunication regulations, there is a risk that radical Islamist ideas could be disseminated with ease. All three cases show the potential role of modern ICT in the process of Islamist radicalisation.

\subsection{Sudan}

\section{The rise of Islamism in Sudan}

In Sudan, "the state religion is Islam, whose adherents, primarily Sunni, account for about $65 \%$ of the population; most of them live in the north. As an important transit station for Mecca-bound African pilgrims, Sudan remains intimately linked with the Islamic world. Arabic, the official language, is the mother tongue of about half the population" (Worldmark Encyclopedia of Nations, 2007). Radical Islam has a long history in Sudan. Since its independence in 1956, the policy of the Sudanese government has been influenced by the promotion of Arabisation and Islamisation. However, for the purpose of this paper, the most important phase in its history began in 1964 when Dr. Hassan al-Turabi (along with several other leading figures of the Muslim Brotherhood) returned from post-graduate studies in London and Paris with a PhD in Constitutional Law. On his return to Khartoum, he was appointed to a faculty position in the School of Law at Khartoum University where he became the most vocal spokesperson for the Muslim Brothers. In October 1964 after a civilian revolution that overthrew General Abbud, the Muslim Brothers created the Islamic Charter Front (ICF), with al-Turabi as Secretary General. In 1965, the ICF also formulated an Islamic constitution, in alliance with the Ansar (al-Sunnah), a Salafi movement originating in Saudi Arabia (Warburg, 2006). This early alliance between the Salafi and Muslim Brotherhood in Sudan excluded Sufi sects such as the Khatmiyyah and Qadriyah. In fact, the Sudanese Muslim Brothers and Salafi of Wahhabi brand believe that all the ideas and actions of Sufism are baseless "heresies and perversions" that ought to be extinguished (Ali, 2012).

After the May 1969 military coup that brought General Ja'far Muhammad al-Numayri and his communist allies to power, some of the Brothers' leaders, including al-Turabi, were arrested and others escaped. After his release from prison in the mid-1970s, al-Turabi and the Muslim Brothers who remained in Sudan prepared for Numayri's move towards an "Islamic path". At the same time, they created the National Islamic Front (NIF), and tied immigrant workers in oil-producing Arab countries to its political and religious agenda. By 1985 about two-thirds of professional and skilled Sudanese workers were employed outside Sudan. They sought ways of smuggling their salaries back into Sudan to help their families, without being taxed. The NIF, with whom many had sympathies, offered them an easy solution; it took their money and, after deducting a percentage, gave it to their families in Sudan (Warburg, 2006). Thus, the NIF not only 
gained the financial support of these immigrant workers, it also secured the support of their families in Sudan for its causes. Strengthened by this financial and social support, the organisation began financing "its own Da'wah (call to Islam) within the army, where it established secret cells of supporters. Thus, it was well prepared for the June 1989 Islamist-Military coup." (Warburg, 2006).

The rule of Islamists since the 1989 NIF-backed military coup has gone against Islamic tradition. Rather than reaffirming the positive social aspects of the Islamic faith, Islam in the Sudan has been the path to political power, and a potent ideological weapon for maintaining that power. After the coup, NIF supporters became dominant in the banking institutions, the building industry, the transport sector and the media. This dominance was at the expense of the Khatmiyyah Sufi sect whose supporters had been dominant in all these sectors. NIF supporters also strengthened their hold over all learning institutions (Box 4.1). This "enabled NIF members, who were mostly graduates, to benefit from the increased opportunities of employment, which included senior posts in the academia as well as diplomatic, economic and political positions abroad." (Warburg, 2006). The fact that even among Muslims, opportunity of access to political power and economic well-being is not equal intensifies elements of fragility and conflict while accelerating the exit phenomenon.

\section{Box 4.1 Islamisation through relief}

Even in the camps for refugees and internally displaced persons it seems that the Islamic relief agencies such as the Islamic African Relief Agency of the 1980s and the Da'wa Islamia, working under the aegis of the NIF and government sponsorship, have been more concerned with religious "needs" than physical needs. The services provided by Islamic relief agencies have been inadequate as they did not meet the basic food and health care needs of refugees. The little comfort that these agencies provided was used to "encourage" conversion to Islam. NGOs like the Da'wa Islamia and affiliated organisations built schools in the relief camps so that internally displaced children "could be taught according to the Islamic curriculum of the Khartoum regime." This appears to suggest that relief funding was also used to support a platform for the spread of powerful ideas rather than providing physical relief and societal development.

Source: State University.com, "Sudan-Educational System-Overview" undated document, available at $\quad$ http://education.stateuniversity.com/pages/1432/Sudan-EDUCATIONAL-SYSTEMOVERVIEW.htm|\#ixzZ1sV7KWfCE, accessed 22 October 2012

The programmes of Islamisation and Arabisation have been accelerated, resulting in politicised educational policy and the marginalisation of those who opposed them. These programmes, among other factors, provoked unrests in Darfur and the Nuba Mountains and resulted in the separation of the mainly Christian South, explained below. 


\section{Recent events}

It took more than 50 years for the people of Darfur to realise that Arabisation and Islamisation of a Salafi brand was actually going hand in hand with their economic marginalisation and exclusion from political power.' This awareness culminated in the rise of the Justice and Equality Movement (JEM), led by Dr. Ibrahim Khalil, who was, like al-Turabi, both a Muslim Brother and Salafi sympathiser. Indeed, even leaders of the JEM spoke out against the impact the promotion of this platform was having on Darfur communities. One of the consequences was the exit of many Darfuri from the Sudanese Armed Forces (SAF) to join the military wing of the JEM. Since people from Darfur constituted the most important pillar of the Sudanese ground fighting forces, and because they populated the lower ranks of non-commissioned officers, their exit made the SAF too fragile to face up to the Sudan People's Liberation Army/Movement (SPLA/M). Once the militia groups had all united under John Garang's SPLA force in 1983, they forced the Government of Sudan to enter into negotiations with the SPLM (Lagu, 2006). These negotiations resulted in the Comprehensive Peace Agreement in 2005, which paved the way for another exit: the separation of the south to become a country in its own right in July 2011.

This separation has made Sudan even more fragile as it lost more than $80 \%$ of its oil revenues. This has deprived it of the financial capacity to provide for the economic and social well-being of its supporters among the northerners. The Government of Sudan has no choice but to proceed with large cuts to the public and private sectors of the Sudanese economy. To compensate for the loss of oil revenue, the Sudanese Ministry of Agriculture has announced plans to develop and expand the area cultivated for cotton in the country (Yazid, 2012). Will it be enough? According to the Economic Commission for Africa, since the separation of the south, "average inflation surged $20 \%$ in 2011 , up from $15 \%$ in 2010 , owing to the rise of food prices and the depreciation of the Sudanese pound." (African Economic Outlook, undated). All these economic trends are precursors to fragility in what was once a middle-income African country. This situation will worsen with recent confirmation of the contract for a pipeline to be built between South Sudan and Kenya (Obala, 2012).

Because of the commitment to the co-ordinative and communicative forms of radical Islamist discourse, the negative impacts of Arabisation and Islamisation in terms of Sudanese territorial integrity seem to have been lost on Islamist leaders, who continue the same policies. Indeed, in February 2012 a coalition of radical Islamist groups threatened to unseat the country's President Omer Al-Bashir if he failed to heed demands for a constitution based on Shari'a laws (AllAfrica, 2012). Sudanese Islamist groups have been lobbying to have the country's 2005 Transitional Constitution replaced with an Islamic one after the secession of the south (ibid.). For this purpose, they created the Islamic Constitution Front (ICF) and proposed a Draft Constitution of Sudan, which is based entirely on Shari'a law and prohibits the appointment of women in the judiciary. In its first conference in Khartoum in February 2012, the coalition presented its members, which included the Salafi Ansar Al-Suna, the Muslim Brotherhood and the Just Peace Forum (JPF), who signed its founding statement calling for the implementation of Shari'a laws (ibid.).

\section{The Arab Spring and the dangers of communication technology}

Today the government is facing another problem: the implications of the Arab Spring, the series of antigovernment uprisings in various countries in North Africa and the Middle East that began in Tunisia in 2010. While it is too early to tell what the long-term impacts of these protests will be, "the only thing that is known for certain is that the use of modern technology and new social media has opened the door to new and creative thinking about how to assemble, organise, plan, and strategise activities ranging from political to social change that are immediately conveyed at a global level" (DeLong-Bas, 2012).

The Sudanese government has two concerns about the Arab Spring. First, unlike other sub-Saharan countries, Sudanese educated elites have deep historical and cultural relations with the Arab world; they may be exposed to "subversive" ideas via their professional and personal networks. Second, these elites 
have access to the Internet and given their interactions with the wider Arab world, they may initiate an elite-led revolution or provoke unrest (Howden, 2012). In spite of the low penetration of the Internet (see below), the government worries about the impact of the Arab Spring among its educated elite. On March 22, 2012 "The Government of Sudan Senior National Congress Party official Mandur al-Mahdi warned opposition groups that its 'cyber battalion' was undertaking online defence operations. In the run-up to the January protests, supporters of the NCP posted messages on the Facebook pages of dissidents, warning them against joining in" (BBC, 2011). While the Arab Spring is still not popular in Sudan, there is little evidence of the size and the nature of the proclaimed "Cyber battalion". Even before the Arab Spring, according to a 2008 US State Department human rights report, the government of Sudan was monitoring Internet communications, and the National Intelligence and Security Service was reading e-mail messages between private citizens (US Department of State, 2008).

\section{The media and the spread of radical ideas}

\section{Television and radio}

While the government is concerned that subversive ideas might reach the population through the Internet, much of the radical Islamist ideas that emanate from Sudan to other sub-Saharan countries are still transmitted through traditional means such as radio and television. With an average literacy rate of $61 \%$ ( $72 \%$ for men and $50.5 \%$ for women), radio broadcasting is by far the most important medium for communicating news within the country (Chalk and Kelton, 2009).

Following the 1989 coup, the government dismissed several broadcasters from Sudan Television because their loyalty to the new government and its policies was considered suspect (Mongabay, 1991). In Sudan, according to Mohammed Ali: "the media that is the press, radio, and television was a tool for the maintenance and expansion of the Islamic faith. The media served the attainment of two broad objectives: it provided religious information regarding ongoing activities and future programs and propagated the principles and thoughts of Islam" (Ali, 1996). The Sudan Broadcasting Service - the governmentcontrolled radio network - broadcasts in Arabic, English, French, Amharic, Somali and other languages, allowing it to reach many Muslim populations in neighbouring countries (Chalk and Kelton, 2009). "In 2003, there were an estimated 461 radios and 386 television sets for every 1,000 people. The same year, there were 6.1 personal computers for every 1,000 people and nine of every 1,000 people had access to the Internet" (Encyclopedia.com, undated). This is significant given the importance of radio in most disenfranchised Muslim communities in and around Sudan. According to Frank Chalk and Danielle Kelton, even though "there were only 250,000 television sets in Sudan in 2002, the GOS has frequently initiated policy changes by first preparing the attitudes of the members of the educated elite, who are numerous among Sudanese with access to TVs and the Internet" (Chalk and Kelton, 2009).

Although the Sudanese constitution provides for freedom of expression, in practice the government limits free speech and the press through intimidation, surveillance and economic control. The government has a monopoly on the propagation of radical Islamist ideas internally and externally. According to Freedom House, the Government of Sudan is one of the world's most repressive regimes for the independent media, which operate under the tightest control. It directly controls radio and television and requires that they reflect its policies, while the "television has a permanent military censor to ensure that the news reflected official views." (International Press Institute, 2005). In its effort to curtail popular unrest, the government uses different methods according to whether it is communicating with educated elites or poor workers and farmers. According to Chalk and Kelton, the government:

...uses Sudan TV and the websites of the Sudanese News Agency to anticipate policy changes and shape the reactions to them among Sudan's educated elite. [It] acts as if it fears and respects the potential for political activism among educated Sudanese. Radio Sudan, on the other hand, addresses poor workers and farmers with little time for politics and anti-government activities. Radio Sudan rarely anticipates policy changes. Rather, it is 
largely a valuable tool for mobilising participation in government-organized mass demonstrations by the poor in Sudan's largest cities, strengthening the government's claims. (Chalk and Kelton, op. cit: 34-35)

Much like the Kingdom of Saudi Arabia and Egypt, the Government of Sudan has established a journalism and mass communication school at the traditional seat of Islamic learning, the Department of Journalism and Mass Communication at Om-Durman University (Napoli, 2002). This means that the primary mission of most accredited Sudanese journalists is to propagate Islamism (Chalk and Kelton, 2009).

\section{Cell phones}

Having established strong control over traditional media and favoured by the limited penetration of the Internet, can the Government of Sudan control the use of cell phones? Unlike most sub-Saharan countries, Sudan's regulatory requirements order telecom networks to disconnect mobile prepaid subscribers if they have no personal information about the customer on record. Because of this, telecom operator MTN alone lost 1.1 million subscribers during the beginning of the second quarter of 2008 (Bevir, 2009). Despite the government restrictions, "in Sudan, a country troubled by war in recent decades, cell phone penetration has reached 45\%" (Rao, 2011). Furthermore, because of the cell phone technology, Internet user numbers are set to rise.

\section{The Internet}

The number of Sudanese Internet users has increased from 30000 in 2000 to 4.2 million in 2011 (10.2\% of the population; see Annex A, Table A.1). According to OpenNet Initiative, in Sudan "The number of home Internet subscriptions increased by a factor of ten between 2001 and 2005, rising from 50,000 to 500,000 . During the same period, the number of Internet cafés more than doubled" (OpenNet Initiative, 2009). However, Internet usage remains concentrated in Khartoum, accounting for 95\% of Internet users. Publicly accessible Internet is available in only $46 \%$ of the country's cities and towns, something operators attribute to low demand.

The majority of Internet users in Sudan rely on dial-up connections (59\%), and very few have high-speed Internet (19\%). While $81 \%$ of universities in Sudan are Internet equipped, most (65\%) still use dialup connections (Diebert, 2008).

Only two Internet service providers (ISPs), Sudatel and Canar, have direct connectivity to the global Internet. Sudan is connected to Saudi Arabia through an underwater fibre optic cable; the domestic fibre optic cable network extends over 11000 kilometres throughout the country (African Economic Outlook, undated).

Today Sudan is facing the Arab Spring, which is pitting the government against Sudanese educated elites. While the government aims to control technologies such as the Internet, cell phone subscriptions and social media, it is doubtful it will succeed. And its repressive tactics could be the cause of its own undoing because they increase conflict, even with its own educated elite, and increase the fragility of the country.

To conclude, the Sudan case study demonstrates how Islamism has increased the fragility of a multiethnic country. Radical Islamists in Sudan are using war, provision of relief to internally displaced people and Salafi religious education to further Arabisation and Islamisation, while attempting to displace local cultures and traditional Sufi religious practices. They have manipulated the government's social services to that end. Since they have a firm grip on power, they are unlikely to be displaced in the foreseeable future without the total collapse of the northern Sudan state. 


\subsection{Nigeria}

Nigeria is home to nearly 60 million Muslims, almost half the country's total population. Islamic radicalisation has taken two paths in Nigeria: 1) an illegal and violent route perpetrated by Boko Haram; and 2) a legal and constitutional route exemplified by the northern states' attempt to impose Shari'a law, echoing the communicative form of radical Islamist discourse (see Section 2). Both forms of radicalisation inspire violence among Muslims and between Muslims and Christians, leading to instability that threatens the viability of the Nigerian state (McCormick, 2005).

\section{Violent radicalisation in Nigeria}

Between 1999 and 2002, Shari'a law was introduced in 12 northern Nigerian states. Since the introduction of the Shari'a the violent form of radical Islamism, now represented by the activities of Boko Haram (described next), has taken shape in these northern Nigerian states. We see in Nigeria how the communicative forms of radical Islamist discourse have begun to have causal effects. The introduction of Shari'a law, for example:

...caused controversy over its compatibility with international human rights standards and the constitution and regarding the position of Christians in those states. It also exacerbated recurrent conflicts between Muslims and Christians. But it was supported by many Muslims.... who had lost faith in secular law enforcement authorities... (International Crisis Group, 2010)

It has also generated new conflicts between opposing Islamic sects; between anti-establishment Islamic groups and the Nigerian state; and between long-established indigenous communities and the more recent "settler" groups (ibid.). It should be noted that many of these settlers are from Sudan, Chad and Niger. They came to Northern Nigeria not only for economic opportunities, but also for security and ethnic, religious and political solidarity with their brethren, who are sometimes Muslim radicals. In fact, many ethnic groups situated at the international borders of sub-Saharan countries are found in two or more countries. This is because the borders inherited from the colonial period did not respect the actual demographic makeup of the region: "The Kanuri ethnic group, found in Boko Haram's heartland of Borno State, are also found in Niger and Chad. The House of Fulani, an even larger Sahelian ethnic group, can be found from the banks of Lake Chad in the east to the Atlantic coast of Senegal" (Baldaulf, 2012). The dispersal of Hausa groups is even wider; they are to be found in northern Nigeria, southeastern Niger, Cameroon, Sudan, Ghana, Côte d'Ivoire and Chad.

Former CIA director Porter J. Goss observed in 2004 how the rise of radical Islamism was threatening to turn Nigeria into a breeding ground for international terrorists (cited in Kamor, 2007). There are groups such as the "Zamfara State Vigilante Service" whose members wear red uniforms and harass anyone suspected of non-conforming to the Shari'a. They carry pistols, machetes and whips and are funded by the governor of Zamfara State (ibid.). Terrorism expert Bestman Wellington made the following topical observation in June 2008:

The porosity of the Nigerian border, economic hardship and religious tensions combine to make these Islamic groups vulnerable to recruitment into dangerous terrorist networks, threatening the security of the country. The alarm raised by police chief Mike Okiro regarding threats to the Nigerian nation by Al-Qaeda extremists might not be backed by intelligence reports, but in Nigeria, particularly in the Muslim north, there are various armed Islamist formations with agendas similar to that of Osama bin Laden. (Kamor, 2007) 
That is why individuals from these ethnic groups who do not possess Nigerian citizenship but are present in Nigeria are currently the main target of the current police repression of Boko Haram (Adisa, 2011).

\section{Boko Haram}

The violent activities of the newly-formed Nigerian terrorist organisation Boko Haram are the direct result of radical Islam ideas that have been developed at the international level and have worked their way into Nigerian domestic politics. Boko Haram garnered international attention in August 2011 after claiming responsibility for a suicide bombing at the United Nations building in the Nigerian capital of Abuja, in which at least 25 were killed and more than 110 wounded (Anti-Defamation League, 2012).

The group's name translates from Hausa as "Western education is forbidden/sinful," although Boko Haram's leaders insist that the name refers not just to Western education, but also to Western civilisation in its entirety (Anti-Defamation League, 2012). The group is also known by its Arabic name, Jama'at Ahl al-Sunnah lil-Da'wah w'al-Jihaad (the Group of the People of the Sunnah for Propagating Islam and jihad). Boko Haram's Arabic name and political ambition of eradicating Western civilisation from Nigeria clearly reveal the effects that global Islamist ideas can have on Nigeria - a resource-rich, middle-income country which borders a number of weaker states (Omonobi, 2011). According to Nigerian newspaper the Sunday Tribune: "sources confirmed that the Boko Haram had hijacked the [Hawala]" Monetary System, used in the Middle East, as its main means of financial transfer and that the operatives have discovered that an otherwise innocent means of funds transfer had been diluted and is now being used for its benefit" (Adisa, 2011). The international money transfer to Boko Haram implies that the organisation is financed from foreign sources that could include Nigerian Islamist expatriates and radical foreign Islamists.

Today there is an alliance among al-Qaeda and its branch in North Africa (AQIM),"' the Mouvement pour l'unicité et le jihad en Afrique de l'Ouest (MUJAO) and Boko Haram. Boko Haram has recently received help from AQIM (Blair, 2012). Ahmad Salkida, believed to be a credible source, maintains that Boko Haram has links with Islamists around the world. For him, "In the past few years the relationship with alQaeda has been about 'capacity building'. But the links are growing" (Africa Works, 2012). Recently, an alleged link-man between the Boko Haram Islamic sect and the Al-Qaeda terrorist network - Mallam Mohammed Ashafa - was apprehended by the Pakistani government through the National Intelligence Agency (NIA) and handed over to the Nigerian Federal Government for prosecution (Nnochiri, 2012).

The presence of al-Qaeda risks worsening the latent conflict between the country's Muslims and Christians. There is also a possibility that radical Islamist ideas may provoke fresh conflict among Nigerian Muslims, because radical Islamists consider traditional Nigerian Muslim practices to be idolatrous and impure. Following Boko Haram's example, recently an armed Islamist group led by an influential Tuareg rebel fighting for autonomy in northern Mali called for the national imposition of Shari'a law, claiming that "it was an obligation for us to fight for the application of Shari'a (Islamic law) in Mali" (video quote by Sheikh Ag Aoussa, spokesman for the movement Ansar Dine, which means Defenders of Islam). ${ }^{\text {IV }}$

Thus, radical Islamists appear to be spreading powerful messages that Muslims must live by Islamic rules and that in order to accomplish this they must undo the secular constitutions of sub-Saharan African states. To do this, they plan to place radical Islamists in strategic government positions so as to drive policies and decision making in favour of Islamism. Meanwhile, young men, women and children must be educated according to Islamic tenets. The messages also make references to daily life such as the prohibition of alcohol in neighbourhoods inhabited by Muslims and criticism of Sufi practices and sheikhs. In recent years, these messages have gained momentum because the social networks and brotherhoods that radical Islamists have succeeded in putting in place have become further empowered by communications technologies such as cell phones, and to a lesser extent the Internet (Prucha, 2010). 
The other type of message that has the potential to drive Nigerian terrorism against the West is radical Islamists' portrayal of Israel, the United States and the West in general as the enemies - not only of their version of Islam but of Islam in general (Terdman, 2007a). In fact, Nigerian radical Islamists "... see the secular West as morally degenerate compared to the 'superior' morality and ethical practices of Islam that promise a return to a righteous society and glorious rewards in heaven" (Langman and Morris, 2002).

\section{The non-violent form of radicalisation}

Not all Nigerian Islamists are committed to violence. There are even those within Boko Haram's ranks who disapprove of violence and have created a new Islamist group called Jama'atu al-Ansarul Musilimin fi Biladi Sudan (Supporters of Islam in the Land of Sudan, but referred to here as Nigerian Ansar). The "Land of Sudan" refers to the historic Sudan that stretches from the Red Sea to the Atlantic Ocean (excluding North Africa and the southern part of the continent). According to a videotaped monologue produced by the group's emir, Abu Usamatul Ansar, the organisation differs from Boko Haram in three noticeable aspects (LWJ, 2012):

1) Ansar does not believe in killing innocent non-Muslims, except in "self defence" or if they attack Muslims. Islam forbids killing of innocent people including non-Muslims. Boko Haram, on the other hand, considers all non-Muslims, and particularly Christians, as enemies who must be killed.

2) Ansar condemned the killing of "innocent security operatives," and said he would not order attacks against them unless they attack him and his loyalists. Boko Haram, in contrast, has attacked police and other security personnel on a number of occasions (e.g. see Rogio, 2012).

3) Unlike Boko Haram, which focuses much of its efforts against non-Muslims in northern and eastern Nigeria, Ansar has vowed to defend the interests of Islam and Muslims throughout Africa.

The video, which was filmed in Arabic, was also translated into English and Hausa, a predominant African language widely spoken in northern Nigeria. While "it remains unclear how many followers of Imam Abubakar Shekau and his Boko Haram organisation have defected to the Nigerian Ansar, and what impact Nigerian Ansar's declaration will have among Islamists in Nigeria and greater West Africa" (ibid.), the group could form alliances with other well-established non-violent Islamist groups in Nigeria. These include the National Council for Muslim Youth Organization and a group of Islamic scholars and leaders who called on the militant Boko Haram group to end its violent attacks against Christians and security forces in the country (SHAFAQNA, 2012).

\section{The role of the media}

In Nigeria electronic and print media play an important role in non-violent radicalisation, especially in the northern parts of the country where conflicts over religion are most prevalent (Alao, 2009). According to Alao, "there are more radios per person in Northern Nigeria than any other part of the country and the people have more access to foreign news than any other part of Nigeria. This is because of the plethora of Hausa programme services available on global radio networks" (ibid.). The Hausa population in Northern Nigeria hear about global events more than any other ethnic group in Nigeria.

Apart from radio, people see graphic images of events in other parts of the world on television. While few people have access to satellite televisions at home, they are widespread in cafés. "There are now many public cafés that have their television permanently fixed to Al-Jazeera and it is not uncommon to see people surrounding these public television sets to watch news, especially those relating to the "War on Terror"' (Alao, 2009). This means that not only Internet surfing, but also radio and television, could initiate the early stages of radicalisation. 
In Northern Nigeria, radical Islamist leaders also use the media to counter Christian evangelisation. The Sultan of Sokoto and the Spiritual head of all the Muslims in Nigeria, Alhaji Abubakar Saad III, and President General of the Jama'atu Nasil Islam (JNI; a political party) vowed in 2007 to counter the upsurge of Christian evangelisation in Nigeria with the message of Islam. He said that the JNI needs to establish a proactive and virile Da'wa (call to Islam) agency to respond to these challenges and rehabilitate, reposition and expand the coverage of schools currently managed by JNI (Shiklam, 2007).

Five years after this declaration, Ummah Radio was created in February 2012. The channel is run under the guidance of Taawunu Information Department and its Alqudus Islamic Information Centre (Qudus Radio, undated). It aims to develop both an FM radio and television channel in an effort to spread Islamist messages to the 45 million Nigerians who are using the Internet from many devices including mobile phones. ${ }^{\vee}$ While there is no proof that the activities of radio, television and Internet messaging are necessarily related to violent radicalisation processes, according to a 2011 Europol report, the boundaries between telecommunication networks, media outlets and Islamist terrorist organisations appear increasingly porous. The Europol report reveals that: "Some media outlets have been specifically created to authenticate statements from a particular terrorist organisation. Occasionally, they also relay communications from other groups; an example is AQIM's media arm al-Andalus, which published a statement from a Nigerian Boko Haram leader in October" (Europol, 2011).

\section{Internet use}

Of all the sub-Saharan countries with significant Muslim populations, Nigeria is the top user of the Internet (29\% penetration). This constitutes $32 \%$ of all African users (including North Africa; see Annex A, Table A.1). Cell phones are used to disseminate information that could alter traditional religious practices and sow negative perceptions of the government. Boko Haram's recent terrorist attacks against the United Nations' office in Nigeria and its attack against Christian churches did not give momentum to popular uprising despite the brutal police repression against Muslims these attacks have provoked. However, when and if ever such a momentum builds up, cell phones would likely be used to provide a degree of coordination for the initial protests. However, analysts have questioned whether the recent Boko Haram's attacks were not the result of the Nigerian police's extra-judicial killings of a number of unarmed Muslims on the street in Maiduguri last year in broad daylight. The Al Jazeera video of this event was widely disseminated among Muslims around the world and gave the impression that there is an open season for killing and hunting down Muslims. ${ }^{\mathrm{VI}}$ It is these types of event that delegitimise moderate voices and promote radicalisation.

Moshe Terdman describes two separate visits he made to Northern Nigeria - in mid-2010 and at the end of 2011 - during which he witnessed people in mosques, at death ceremonies, birth celebrations, and marriage ceremonies listening to cell phone audio recordings and watching video footage of Muslims' suffering in Palestine, Afghanistan and Iraq (Terdman, 2007b). On various occasions, he also observed people listening to audio recordings of a Salafi mufti ranting against a local Sufi and Sufism in general. The topic was how Sufi Islam is unauthentic and idolatrous, an innovation prohibited by Islam. 


\section{Policy responses}

In Nigeria, policy responses to curtail religious radicalisation have taken three forms:

1) Addressing violent interactions between Christians and Muslims. This includes efforts to promote harmonious relations between the two religious groups in the country. "Considerations for ethnicity and national politics have also affected the fight against Islamic radicalisation. In responding to the problems, governments have had to balance ethnic and religious sentiments in order to ensure that allegations of bias are not levelled against them" (Alao, 2009: 80).

2) Ensuring that radical religious views are suppressed before they have any security implications for the country.

3) Training armed units of the Nigerian Defence Force to handle insurgencies emanating from radical groups (Alao, 2009).

Recent attacks by Boko Haram (Agenzia Fides, 2012) may lead the government to investigate the networking aspect of the radicalisation process, because it has become increasingly obvious that the violent and non-violent forms of radicalisation may feed on each other's strengths. This is not an easy task because it is difficult to understand all the nuances of political Islam in Nigeria. The United States Institute for Peace also suggested that a greater understanding of the nuances of political Islam is a necessary condition for formulating policy recommendations to respond to Islamist radicalisation processes in subSaharan Africa (Dickson, 2005).

\subsection{Chad}

Chad is a country suffering from utter poverty and a latent conflict between the Muslim North and the Christian South. The country is situated at the crossroads between Arab, African and Western influences. It is also in a transnational area between an Islamic zone on one side, and an animist and Christian zone on the other. This is reflected in the country itself, which has a north-south geopolitical divide. The north of Chad came under Muslim influence from Sudan and North Africa. "The majority of Chadian Muslims owes allegiance to the Tijaniyyah Sufi order" (Ousman, 2004: 88). Much of Chad's history after independence has been riddled with intermittent episodes of civil wars that resulted in the presence of both Islamic and Christian NGOs. By 2009, there were as many as 14 transnational Islamist NGOs present (Kaag, 2010). Officially Chad is secular and non-Arab. However, literary Arabic is making its way into the education and public administration sector under the impulse of Islamists. "The nation's official business languages are French and Arabic but over 100 languages and dialects are spoken. Due to the important role played by itinerant Arab traders and settled merchants in local communities, Chadian Arabic has become a lingua franca" (Wikipedia undated [d]). Many Muslims and non-Muslims speak local Arabic; increasingly some Chadians in the north are learning literary Arabic.

Coincidently, after the June 1989 coup that brought the National Islamic Front (NIF) and al-Bashir into power in Sudan (see Sudan case study), and the Islam in Africa Organisation's conference in November 1989, the government of Chad also changed and Idriss Deby came to power through a military coup orchestrated in Sudan (Zoomtchad, 2010). Idriss Deby filled his key posts with people selected by Dr. Hassan al-Turabi, the leader of the NIF. As noted in the Sudan case study, Dr. al-Turabi is a radical Islamist with great influence in Darfur. He was the spiritual leader of the Sudanese government before his dismissal and house arrest in 2004-05. He has never hidden his interest in propagating his radical Islamic ideas within Chad.

The emblematic figure in this movement to "conquer" Chad is another Sudanese - Sheikh Hassan Hissein Abakar - a native of Darfur and member of the political bureau of al-Turabi's party (Zoomtchad, 2010). Sheikh Abakar arrived in Chad only one week after Deby's seizure of power. Sheikh Abakar was first appointed policy advisor in the Chadian presidency, then became imam of the King Faisal Mosque of 
N'Djamena and president of the Chadian Islamic Committee. Technically he is the spiritual leader of the Chadian Muslim community. These developments are significant because for the first time in the history of Chad the spiritual leader of the Muslim community is not a Chadian.

Sheikh Abakar's mission is to transform Chadian Islam from its traditional form into a new one in accordance with the ideas diffused by the Islam in Africa Organization (see Nigeria case study). Sheikh Abakar receives his inspiration from al-Turabi. It should be noted that the Islam practised in Chad is moderate and limited to the private domain in the sense that there is no Islamic political party vying for power in Chad. Even though there is a sense of belonging to the global Islamic community (Umma), until now the experience of Islam by Chadian Muslims has had no political connotation, at least from the point of view of the ordinary citizen. The objective of Turabi's men and women in Chad is to transform the ordinary Chadian Muslim according to the radical Islamist policy of rebuilding the Muslim individual (International Crisis Group, 2008).

Sheikh Abakar's mission was funded by Gadhafi's Libya, Saudi Arabia and Sudan (International Crisis Group, 2008; Kaag, 2008). The money provided by these countries was used to build mosques, modelled on Sudanese mosques, even where there weren't enough people to fill them. The Sheikh has placed his men in all these mosques. In addition to performing daily prayers, these mosques also serve as madrasas and Arabic primary and secondary schools with the chief objective of communicating radical Islamic ideas to young Chadian Muslims.

\section{Positive impacts of radical Islam in Chad}

It is very well known in Islam that "almsgiving or charity represents one of the five pillars of the faith. This is known in Arabic as zakat. Much of this funding goes directly to non-governmental organisation (NGO) efforts. As such, the strategy of radical Islam relies heavily on this pillar of the Islamic faith to fund social welfare programs that provide for a base of popular support and mobilising radical Islam's cause" (Servold, 2010). The zakat is the obligation of all Muslims; in Chad, non-violent Islamists use "a structure of charitable non-governmental organisations to formally pursue youth, health, religious, education, and social welfare service programs" (Servold, 2010). Islamist NGOs were involved in the construction of mosques and water wells and provided much-needed support for orphans, health care and education. "The construction of wells and mosques often goes hand in hand, based on the idea that Muslims need water to purify themselves before praying...Caring for orphans is also rooted in Islam: the Prophet himself was an orphan, and many hadiths (sayings of the Prophet) point to the value of providing care for these children" (Kaag 2010: 10).

During Chad's civil wars Arab countries' investments and bilateral and multilateral aid became increasingly important. Saudi Arabia, in particular, helped found and continue to finance King Faisal University, while multilateral aid has mainly been provided through the IsDB and the Banque Arabe pour le Développement Economic en Afrique (Mustafa and Razak, 2012).

Chad's ties with the Arab world are growing as increasing numbers of Chadians are studying in neighbouring Sudan, Egypt and Saudi Arabia. Many immigrant workers in Saudi Arabia and Libya keep in touch with their families back in Chad.

\section{Negative impacts of radical Islam in Chad}

The intensification of these relations with Arab countries has stimulated processes of Islamisation and Arabisation in this country. In the Saudi-funded Sheikh Abakar mosques, sermons denounce Chadian customs which do not conform to the rules of "true Islam". Women and particularly young girls are the primary targets of these "communicative" activities (see Section 2) since their transformation is essential to the radical Islam policy of building new families. Moreover, women are encouraged to divorce husbands whose social habits do not conform to the rules of Islam. ${ }^{\text {VII }}$ It was in this context that the wearing 
of hijabs and burqas has appeared and spread rapidly, replacing the traditional Chadian veil, which is considered "too sexy" for a Muslim woman (International Crisis Group, 2008). In some districts of Ndjamena, it is impossible for young girls to wear jeans and several cases have been reported of young boys stoning young girls wearing trousers in the street. Traditional baptism, burial and funeral ceremonies have also been replaced with new practices (ibid.). The Sudanese Sheikh created an association of Muslim executives (Union des Cadres Musulmans du Tchad - UCMT) to co-ordinate radical political actions. This brings together high-level managers in the administration right up to the Presidency, the private sector, parliamentarians, members of the ruling party and journalists. This reflects the policy of favouring Muslims in strategic government positions (ibid.).

The government is pursuing a consultative process to develop new legislation. However, the UCMT has been instrumental in blocking the secular family code proposed by the government (Zeidane, 2004). In 2002 it submitted an alternative draft code to the government and produced a memorandum referring to the constitution and other conventions, in which it argued that Muslims should be governed by a family code inspired by Shari'a law. The UCMT draft code contradicts Article 134 of the Chadian Constitution, which clearly indicates that legislative proposals are the exclusive domain of the Executive and Legislative branches of the government (Ablaye, 2005).

The UCMT's draft code also questions the country's judicial organisation and proposes recruiting special judges. Being a Muslim would be the most important criterion for selecting these special judges, and the High Council of Islamic Affairs would make the selection, instead of the High Judiciary Council. This latter is the body mandated by Chad's Constitution to appoint, promote and discipline judges. On this point too, the draft Code could be considered as being unconstitutional. Its provisions were designed to apply to Chadian Muslims only and expatriates living in Chad, and then to non-Muslim Chadians if they so desired. A law applicable to Muslims only would undermine the government's objective of codifying legislation that would apply to all without discrimination (Ablaye, 2005).

UCMT's legislative proposal calls for a ban on marriage between a Muslim woman and a non-Muslim It also allows a husband to physically punish his wife using a whip. These and other provisions are in clear contradiction of the Chadian Constitution, which proclaims the equality of Chadians of both sexes, and prohibits abuse, degrading and humiliating treatment. The prohibition of degrading treatment is also contained in Article 5 of the 1948 Universal Declaration of Human Rights and the African Charter on Human Rights. Article 30 of the 1948 Declaration states that nothing in the Declaration may be interpreted as implying, for a group, a right to engage in an action for the destruction of rights and freedoms of other groups.

As in Sudan, Sufi groups in Chad are beginning to suffer from government restrictions on their organisations and practices. For example, according to the US Department of State:

The government [of Chad] banned Al Faid al-Djaria...a Sufi group in the Kanem, Lake Chad, and Chari Baguirmi areas. The Director of religious and traditional affairs, the High Council for Religious Affairs, and certain ulama (religious authorities) objected to some of Al Faid al-Djaria's customs, such as the incorporation of singing, dancing, and the intermixing of sexes during religious ceremonies, which they deem un-Islamic (US Department of State, 2008).

This ban is a direct effect of both co-ordinative and communicative forms of radical Islamist discourse. It prohibits what is considered to be the un-Islamic elements of Sufi ritual, which means the prohibition of Sufism altogether, because Sufism cannot be practised without chanting, singing and dancing. 


\section{The role of the media}

Unlike Sudan, Chad is a desert in terms of telecom regulations. In September 2010 the penetration rate of cell phones was estimated at $24 \%$ for a population of 10.7 million. ${ }^{\text {VIII }}$ According to the US Department of State "newer telecommunications methods, including mobile phone and internet services, are private and highly competitive" (US Department of State, 2011). As in many sub-Saharan countries:

The mobile sector is growing fast under competition between two foreign-owned networks - Bharti Airtel (formerly Zain), and Millicom (Tigo). The national telecom and fixed-line operator, Sotel Tchad (ST) was participating in another mobile network in partnership with Orascom Telecom until it ceased operations in 2004 over legal disputes between the shareholders" (Budde.com, 2012; a telecommunications research site on the Internet).

According to Budde.com: "despite being Africa's latest exporter of oil, Chad has one of the least developed telecommunications markets in the world. Penetration rates in all market sectors - fixed, mobile and Internet - are well below African averages" (Budde.com, 2012 and see Annex A). All long-distance connections, national and international, are currently made via satellite. However, the World Bank-funded Central African Backbone (CAB) finally brought fibre optics to the country in 2012 (ATP, 2011). Even though the Internet has played a minor part in the radicalisation of Chadian Muslim communities to date, the introduction of fibre optics will open up new possibilities for linking Chadian communities to the larger Arab and Islamic world, thereby accelerating the processes of Arabisation and Islamisation.

Like their counterparts in Nigeria, Chadian Islamists will soon begin using Internet-enabled radios and television and create websites of their own. In the past, Chadian Islamists disseminated radical Islamist messages using audio tapes. In the 1960s and 1970s, Egyptian radical Islamist clerics such as Abdul Hamid Kishk and Sayyid Qutb used recorded audio tapes to broadcast their messages. The messages were always about events in the Middle East, the Israeli-Arab conflict, the suffering of the Palestinians at the hands of the Israelis and the corrupt nature of both Western societies and secular governments of the Muslim world. These messages took months to reach sub-Saharan Africa and even years for those who needed translation from Arabic to their native tongue. And only those who had access to tape recorders were able to listen to these messages; the rest had to rely on the interpretation and translation of these messages by their community and religious leaders.

With the advent of fibre optics in Chad, it will be easier to establish websites and Internet-enabled cell phones, making it easy for radical discourse to reach communities over a wide area very quickly. Already Chadian opposition websites such as www.tchadactuel.com, www.zoomtchad.com, www.tchaonline.com, www.letchadanthropus.com and many other bloggers are very active in their attempt to motivate an uprising against the Chadian regime. The arrival of fibre optic cables in Chad will soon provide an effective way for these Chadian groups (Islamists and others) to promote what some observers call a "global dialectic": "where awakening, awareness, activism and radicalism can be stimulated at a local level and then mobilised into a wider process of dissent and protest" (Hoffman, 2006).

\section{Policy responses}

The Chadian president is understandably in a dilemma: either he follows Islamist policies and risks a separatist movement by the southerners, or he rejects radical Islamist ideas and risks alienating radical Muslims who constitute his fighting forces, mainly his Islamist Zaghawa brethren from Darfur (Zoomtchad, 2010). The other risk is an open conflict among Chadian Muslims - between those who welcome radical Islamist ideas and those who oppose them. The latter are locally known as the Francophones because they have been educated in French and speak local Arabic but do not identify themselves with radical Islamist ideas. To remain in power, the President appears to have chosen the same strategy as his Sudanese counterpart, President Umar Hassan al-Bashir. Like al-Bashir, Deby may be tempted to wage war against Southern Chad if this region insists on separating like Southern Sudan. For now, however, he 
seems oblivious to the fact that the incremental radicalisation of the Chadian Muslim communities is the price of his hold on power. ${ }^{\mathrm{IX}}$

The Government of Chad appears undecided as to whether or not to allow a separate family code for Muslims. This inaction has had a number of concerning outcomes, including the tendency for radical Islamists to use funerals, religious sacrifices, collective prayers, baptism and marriage ceremonies as opportunities and places of choice to propagate their conception of the Family Code. Unsurprisingly, more subversive awareness campaigns sometimes encourage hatred (Ablaye, 2005). Allowing these trends to further manifest risks reigniting the civil war between the Muslim north and Christian and animist south.

However, "government officials, including the President, regularly acknowledge the value of harmonious relations among religious groups and celebrated religious diversity. The President meets regularly with religious leaders, most recently discussing social matters and Arabic-language schools with the country's Catholic Bishops" (US Department of State, 2010). Foreign-based religious groups are required to register with the Ministry of the Interior and according to the US Department of State's report, this registration does indeed take place. However, "despite popular perception to the contrary, registration does not confer tax preferences or other benefits" (US Department of State, 2010). According to the same report, in order to regulate groups who advocate actions that would heighten sectarian tensions, the Government of Chad has pledged to prohibit activities that do not "create conditions of cohabitation among the population" (US Department of State, 2010). For this purpose, it has "closed certain Qur'anic schools that compelled children to beg for food and money. The government was also collaborating with the High Council of Islamic Affairs and the Islamic Scientific and Cultural Organization on building two large Qur'anic schools...to replace those that are closed" (US Department of State, 2010).

According to the US Department of State, the Government of Chad has generally enforced legal and policy restriction selectively. In 2010, the government maintained the ban imposed almost six years ago on Al-Montada Al-Islami, The World Association for Muslim Youth, the Mecca Al-Moukarrama Charitable Foundation, and Al-Haramain Charitable Foundation for promoting violence to further religious goals. The ban was not necessarily enforced and evidence indicated that these organisations continued to operate (US Department of State, 2010). This is because Islamist groups appear to be defiant and the government is not interested in being in open conflict with them. 


\section{NOTES}

' The Darfur Conflict was a guerrilla conflict or civil war centred on the Darfur region of Sudan. It began in February 2003 when the Sudan Liberation Movement/Army (SLM/A) and Justice and Equality Movement (JEM) groups in Darfur took up arms, accusing the Sudanese government of oppressing non-Arab Sudanese in favour of Sudanese Arabs.

"Hawala is an Arabic word for those who transfer money. It is "an informal value transfer based on the performance and honour of a huge network of money brokers, which are primarily located in the Middle East, North Africa, the Horn of Africa, and South Asia. It is basically a parallel or alternative remittance system that exists or operates outside of, or parallel to traditional banking or financial channels." Wikipedia, downloaded on March $20^{\text {th }}, 2012$ from http://en.wikipedia.org/wiki/Hawala.

III AQIM stands for al-Qaeda in the Islamic Maghreb - it is a branch of the international terrorist network based in the Saharan states of Mali, Niger and Algeria.

IV Baba Ahmed, "Video-Mali: Iyad Ag Ghaly, le leader d'Ansar Dine se met en scène", Jeune Afrique, 15/03/2012, downloaded on March 20, 2012, from www.jeuneafrique.com/Article/ARTJAWEB20120315171453/mali-att-djihadrebellion-touareguevideo-mali-iyad-ag-ghaly-le-leader-d-ansar-dine-se-met-en-scene.html.

$\checkmark$ Data compiled by the International Telecommunication Union in the last 12 months of 2010. Estimates are derived from either household surveys or from Internet subscription data.

${ }^{V I}$ The video showed the killing, along with similar news of drone attacks in Afghanistan, tortures in Abu Graib prison in Iraq, and accounts of tortures in Guantanamo Bay by released prisoners. See the Youtube link: www.youtube. com/watch?v=JBSt5o6F20l\&feature=related

VII This information is based on interviews conducted by the author, who travelled to Chad in December 2011

VIII "List of mobile network operators of the Middle East and Africa", http://en.wikipedia.org/wiki/List_of mobile_network operators_of the_Middle_East_and Africa\#Chadl

${ }^{\text {IX }}$ According to the International Crisis Group (2008): "Islamic practice in Sudan and Chad is directly subject to the influence and expansion of Wahhabism, imported from Saudi Arabia. Although this influence has taken on political dimensions in a triumphal, even intolerant, state-sponsored Islam in Sudan, it is more cultural in Chad, as secularism continues to prevail in the country's institutions. Among the reasons for Sudan's support for the rebellion against Deby was the desire to install a regime under Turabist influence in N'Djamena." 


\section{International policy responses to date}

The phenomenon of radical Islam is new. In the 1990s, it became clear to European countries and a number of North African governments "that radical Islam had external sources..." (Jesús, 2004). Both Europe and North Africa acknowledge that terrorist groups benefit from the lack of border control and cooperation among states in the region (ibid.). This acknowledgement has led to better co-operation between Algeria and Libya, and between Algeria and Mali, making it possible to crack down on sources of weapons. Based on this co-operative experience, since September 112001 the Arab Maghreb Union has worked to develop common criteria for the joint analysis of terrorism (ibid.). Over the same period, France, the United States, the United Kingdom and a number of Saharan and Sub-Saharan countries realised that the Sahel was on the verge of becoming a new sanctuary for Al-Qaeda (Bayart, 2010). This triggered a number of security measures that appeared to be oriented more towards the War on Terror than towards processes of radicalisation. More recently, however, important donors such as the United States and European Union have begun to adapt their efforts to tackle the processes of radicalisation (see Section 5.2). The European Union considers that transnational organised crime, international terrorism, mercenary activities, trafficking in human beings and drugs, as well as the illicit trade in natural resources, are major factors triggering widespread conflicts and weakening of state structures in Africa (Lyman, 2008).

\subsection{Military responses}

On the military front, in 2003 the US African Command was put in place (US Africa Command, 2011). This involves co-operation between the United States, United Kingdom and Sub-Saharan countries in intelligence capacity building, sharing of information, financial control, coastal security and, on occasion, extradition (Lyman, 2008). Since October 2011, Kenyan military forces and the African Union Mission in Somalia have been battling the activities of the Al-Shabaab terrorist group across the Horn of Africa (International Crisis Group, 2012). In West Africa, as of October 2012, both France and the United States have been urging UN Security Council to approve a West African-manned military intervention in Northern Mali against Islamist forces that have occupied the region since March 2012 (Ira, 2012). On 11 September 2012, under the leadership of the European Union (EU), 11 North African, Saharan and Sub-Saharan countries gathered in Algiers to build capacities for efficiently fighting the traffic of prohibited materials and terrorism (Afrique Expansion Magazine, 2012). On the legal front, under the leadership of Algeria, a number of sub-Saharan countries have agreed to create a legislative environment adapted to international standards to fight terrorism (L'Expression le Quotidien, 2012).

\subsection{Social, economic and political responses}

The above responses have addressed terrorism, but not the processes of radicalisation per se; these efforts should take place on the political, social and economic fronts. Dealing with radicalisation is not the same as countering terrorism. While terrorism can be countered by security and military measures because it is an unlawful act of violence, radicalisation is a process that takes place in many lawful and non-violent settings, such as through charity organisations, the distribution of relief to refugees, religious sermons, electoral processes and the media to name a few. Therefore, it is my view that countering radicalisation requires political, social, economic and legal measures rather than military and security responses, which could exacerbate processes of radicalisation.

In 2006, the French government indicated it would seek to intertwine its military struggle against terrorism with a policy which addresses the root causes in order to prevent the radicalisation of populations and recruitment of new terrorists. At the time, one of the causes of radicalisation was considered to be the ongoing diplomatic tensions among Arabs and Israelis in the Middle East (Chichizola, 2006). Since then, moving beyond diplomacy, American and European Union responses to radicalisation have aimed at removing the structural conditions, political grievances and other problems that feed into radicalisation 
processes, as well as the social processes and group dynamics that facilitate recruitment, involvement in, or support for radical groups.

\section{The US response}

In its new strategy for sub-Saharan Africa, the United States recognises the efforts made by individual countries "to broaden political participation and reduce corruption" (The White House, 2012). Such efforts can strengthen the mutual obligation and trust between the states and their citizens and decelerate the exit phenomenon. However, the US government acknowledges that "there is more work to be done to ensure fair electoral processes, transparent institutions that protect universal rights, and the provision and protection of security and public goods" (ibid.). This message addresses elements of fragility at the political level. The US also gives priority to preventing conflicts, mitigating mass atrocities and holding perpetrators of atrocities accountable (ibid.).

However, encouraging national governments to uphold the rule of law in dealing with their citizens may not be enough without a policy for helping those in need of economic and social assistance. This is why the US government also aims to "empower marginalised populations and women." This social aspect of the response is coupled with the objective of providing relief to humanitarian crises and promotion of resilience programmes "to prevent the weakening or collapse of local economies, protect livestock, promote sustainable access to clean water, and invest in programs that reduce community-level vulnerability to man-made and natural disasters" (ibid.: 6).

\section{The EU response}

Similar to the United States, the European Union (EU) also addresses elements of fragility in sub-Saharan Africa through its commitment to good governance, human rights and democracy (EC, 2008c). This trend underscores the realisation that processes of radicalisation are different from acts of terrorism. Unlike the United States, however, the EU explicitly links the need for economic resilience and prosperity to investment in the educational sector. The EU has proclaimed that primary education should be provided to all (though it does not offer any details of the investment required; Council of the European Union, 2007). This focus reflects the links between the lack of economic resilience and widespread illiteracy in the African continent. There is also awareness in Europe that radicalisation and recruitment of youth to extremist groups is "an international phenomenon, where much of the terrorist threat has roots in parts of the world beyond the EU" (EC, 2008c). Consequently, the EU response aims to expand co-operation and assistance to priority third countries, which include those in "North-Africa, the Middle East and South East Asia" (EC, 2008c: 13). For the EU, "an international dialogue and alliance between cultures, faiths and civilizations is crucial in order to address the motivational and structural factors underpinning radicalization" (EC, 2008c: 13).

For these policy measures to succeed, however, structural problems that are specific to each country need to be identified and long-term measures should be clearly differentiated from those that deal with immediate needs. Beyond the general policy statements on addressing the political, social and economic aspects of radicalisation, international donors and their partner developing countries must clearly identify problems that require both mitigation and preventive measures. Policy responses to Islamist radicalisation in Sudan may be different to those developed for Nigeria or Chad. Therefore, it may be critical to disaggregate regions and countries for analysis with the objective of determining particular problems, since all countries do not face the same elements of fragility that make groups and communities susceptible to radicalisation. Large international donors such as the EU and US should encourage regional organisations, such as the African Union and ECOWAS, to sponsor case studies to determine specific factors that lead to radicalisation in individual countries.

There is no evidence of co-ordination between the policy responses developed by the United States and the European Union on the one hand, and responses by sub-Saharan states on the other. Above all, there 
is a lack of solid understanding of the specific factors that generate and sustain radicalisation in particular cases. This is because the efforts of national governments are still overshadowed by the War on Terror and tend to consider, mistakenly, non-violent forms of radicalisation - particularly those occurring in mosques and other social and religious gatherings - to be benign.

Moreover, it is not clear whether the policy responses aim at mitigating existing radicalisation processes or preventing them. While ongoing processes of radicalisation could be addressed by legal means and political dialogue, preventing radicalisation from taking place would require interventions and investments at social, educational and economic levels. Based on the current ambiguity as to whether the problem is one of active recruitment into violent radical Islamist groups or instead one of tacit or explicit community support for these groups, better assessments of country-specific issues of radicalisation would bring clarity in guiding the policy responses. While active recruitment could be dealt with by legislative and security measures, tacit and explicit community support for Islamist groups requires active measures at the political, social and economic levels. This is based on the use of electoral processes and economic and social aids, which Islamic groups provide to those in need to propagate their destabilising ideas. All responses seem to ignore how the broader political, social and economic environment permits violent radical Islamist groups to organise and operate (Ibrahim, 2012; Robin, 2012). The identification of the components of this "enabling" environment may allow for the development of more targeted and efficient responses.

\subsection{Current research on radical Islam}

Research on radical Islam has been overshadowed by the global war on terrorism; less attention has been paid to understanding the potential of Islamist ideas to form destabilising political movements in already fragile and conflict-affected states in Sub-Saharan Africa. For example, the study on "The Use of the Internet by Islamic Extremists" (Hoffman, 2006) was limited to al-Qaeda's use of the Internet for propaganda, recruitment, fund-raising, terrorist training and planning for attacks, but does not mention sub-Saharan Africa (ibid:: 6). The research recommended the development of "...capacity in the information sphere among our allies and coalition partners by helping them to directly and effectively counter radical jihadi propaganda..." (ibid.: 20). David McCormack analysed Islamist activism in Nigeria and Kenya and documented the role of Saudi Arabia in inspiring and financing this activism. However, he does not address the role of modern technologies in empowering and spreading Islamist messages. He notes that, "far from advocating immediate, armed revolution, Islamists have become extremely adept at exploiting local conditions to advance their agenda through political and social warfare" (McCormack, 2005).

Angel Rabasa, of the Rand Corporation, examined “...the complex ethno-religious landscape in East Africa, the characteristics of the East African environment that have produced failed or weak states susceptible to exploitation by radical Islam in East Africa extremist groups, and the factors that have contributed to the emergence of these groups" (Rabasa, 2009). While acknowledging that a purely military solution to radical Islamism is doomed to fail, Rabasa proposes assisting the governments of the region "in gaining better control of their borders, both land and maritime," while deterring Eritrea from supporting radical groups in East Africa. In order to reduce the influence of foreign Islamist organisations, he further proposes 1) identifying mainstream and Sufi Muslim sectors and assisting them in propagating a moderate interpretation of Islam; and 2) de-legitimising terrorism (ibid.) Whilst Rabasa's work makes an important contribution to exposing some of the social infrastructures supporting radical Islam in East Africa, his analysis also does not take into account the role of modern technologies in spreading Islamist messages. 


\section{Strategic entry points}

In supporting fragile and conflict-affected states that are being infiltrated by radical Islamism, international donors should tackle two related phenomena: (1) the endogenous exit phenomenon due to weak national integration, fragility and abject poverty; and (2) the process and speed with which radical Islamism is spreading throughout sub-Saharan Africa. These phenomena can be tackled by focusing on two main entry points:

1) regulating the telecommunication market and use of the Internet and social media; and

2) improving education.

Regional and international co-ordination is also necessary to sponsor a dialogue with radical Islamists which could help to moderate their unilateral attitude and more aggressive dictates, such as outdated restrictions on women's inherent rights as human beings, and violence and intolerance towards those who do not share specific views.

\subsection{Regulating the telecommunication market, the use of Internet and social media}

While the Internet still remains a luxury product for most in Sub-Saharan Africa, the cell phone market is burgeoning. Cell phone devices are currently used to disseminate radical Islamist discourses searching to alter traditional religious practices and sowing negative perceptions towards secular governments. With the advent of Internet-enabled cell phone devices, radical Islamist thoughts are being disseminated widely without the knowledge or supervision of state institutions. The whole subcontinent is arguably a regulatory desert. The implications of these technological developments are obvious in fragile and conflict-ridden states. Without any form of regulatory control, the speed with which mobile networks are penetrating the subcontinent will only hasten the process of disengagement by disaffected Muslim segments of the citizenry. This is why the following points are important:

1) National regulators of telecommunications markets must insist that cell phone service providers are only allowed to sell cell phones to consumers who can provide contact information. Currently no African country is listed among the "enemies of the Internet" (Faris and Villeneuve, 2012) since no African state has taken measures to ban the Internet. While this study does not advocate for the censorship of Internet access, the cell phone market is growing at an exponential rate, so some form of control is advisable.

2) National governments should be encouraged to number all dwellings. Infrastructure projects and requests for infrastructure development by fragile states should include, among other things, a focus on numbering dwellings, particularly in large urban areas. This is a matter of national and international security. In sub-Saharan Africa, controlling access to and content on the Internet is difficult because most individuals are born, raised and die without being formally registered. Even when identity cards are issued, often they are not connected to physical addresses. Most dwellings have no civic numbers. Thus, the Internet - with its entire social media application - is now penetrating this gap in civic control and general disorder with the potential of accelerating the exit phenomenon. 


\subsection{The educational dimension}

Proactive measures to counter radicalisation should begin with the education and well-being of children and young adults:

1) International donors should help to bridge the gap left by many fragile states' disengagement from the social sector, particularly education. This disengagement has led to the burgeoning of uncontrolled private schools, which can promote radical ideas among students.

2) National governments should be encouraged to promote secular education and to promote education as an important means of breaking the endless cycles of abject poverty that have plagued sub-Saharan countries for generations. This approach should also be reflected in external security and development policy.

3) The selection process for national and international awards for higher education bursaries and scholarships should be transparent. Few young people from poor backgrounds win bursaries and scholarships; these tend to go to students who have connections with state officials. Bursary and scholarship opportunities should therefore be better linked to credible partner institutions elsewhere in the region and sub-region.

4) The implementation of national standards at primary and secondary levels of general education should be enforced in both private and public schools.

5) The education of girls should be mandatory and should be coupled with the prohibition of underage marriage.

Many of the United States and European Union policy responses seem to be heading in the right direction. However, in light of recent events in sub-Saharan Africa, policy responses should be better coordinated globally and target both passive and active forms of radicalisation. Developed countries which have expertise in education policy and regulating communication technologies should engage urgently with sub-Saharan countries. Both the US and EU efforts could complement policy responses by subSaharan governments, particularly in the development of legal standards to deal with Islamist propaganda and other standards for controlling access to the Internet and social media. 


\section{Conclusions and further research}

This paper has exposed a number of trends that indicate that alongside terrorism and political violence, radical Islamism is making progress in spreading its destabilising ideas in many countries of sub-Saharan Africa. Based on the author's field research in Nigeria, Cameroon and Chad it is clear that radical Islamists are influential in Darfur, Chad, Northern Nigeria, Cameroon, Mali and Niger. The result is an acceleration of the phenomenon of "exit" by disenfranchised communities. When combined with radical Islamist ideas, this exit phenomenon not only delegitimises state institutions, it also weakens the social infrastructure on which the traditional form of Islam in sub-Saharan Africa is based. One of the major factors in this process of radicalisation is the construction of mosques and Islamic centres serving to indoctrinate sub-Saharan youth. While the ultimate strategic goal of radical Islamists is the re-creation of the Caliphate, the operational undertaking and tactics include the creation of new Muslim individuals as the basis for the constitution of new families, communities, societies and states run according to radical religious precepts.

In the dissemination of radical Islamism's ideas and the deployment of its strategies and tactics, the teaching of Shari'a is paramount. It is for this reason that many sub-Saharan youth are recruited in Middle Eastern universities - especially the University of Omdurman in North Sudan - to be trained in creeds and branches of Shari'a so they can then carry the messages of radical Islamism back to their respective homelands.

In lieu of armed jihad, they support aggressive policies to transform governmental and public sectors into radical Islamist networks acting as transmission belts for radical social policies developed and coordinated outside the subcontinent. In Sudan and Northern Nigerian states radical Islamists have taken over the judiciary; in Chad the secular constitution and judiciary are also under great pressure from Islamists to allow the creation of a separate civil code applicable to Muslim individuals and families. In both countries Islamist judicial activism risks re-energising dormant violent antagonism between Muslims and non-Muslims. The outcome may be secession wars between their northern and southern regions.

The penetration of information and computer technology into sub-Saharan Africa could magnify this impact, especially in the absence of meaningful and workable regulatory control mechanisms. The shifting of traditional communications structures from a top-down to a polycentric form could further accelerate the phenomena of "exit" and flight.

\subsection{Further research}

Further empirical research should focus on measuring how many schools, Islamist centres and mosques are financed by Arab countries in sub-Saharan Africa, and how many African students have been sent to study abroad, particularly in Sudan, Saudi Arabia and Egypt. One interesting area of research would be the number of African students who have been trained in Shari'a since 1989, and how many were trained to teach in the universities of their country of origin or other African Islamic universities or who hold influential positions in the public sector. This research is important for determining the depth and scope of Islamism social and political networks in sub-Saharan Africa and the way in which this phenomenon has "socially re-engineered" sub-Saharan African states. Such research could provide some important insights into the impact of powerful ideas elsewhere.

Finally, it seems that many scholars feel that the poor coverage of telecommunication networks and power grids in sub-Saharan Africa mean it is not valid to focus on the role of ICT in spreading radical Islamist ideas and messages in the region. This contrasts with studies of the Middle East, where the Arab Spring has steered the research focus towards the communication of ideas through social media.' Research into these significant social movements suggests that more attention should be paid to the role of ICT in spreading ideas of many different guises and motivations. Due to the destabilising impact of radical 
Islamist ideas in states which are already trapped in a spiral of conflict and fragility, it is my view that this area is ripe for further investigation. This is particularly the case for two reasons:

1) Few low-income African states have yet been recipients of international aid supporting counterterrorism. Indeed, a recent report commissioned by the Canadian Government concludes that overseas "aid" supporting counterterrorism prioritises recipient countries which already have both the political will and the existing infrastructure to engage in counterterrorism."

2) Fibre optics are now arriving in the sub-Saharan part of the African continent.

\section{NOTES}

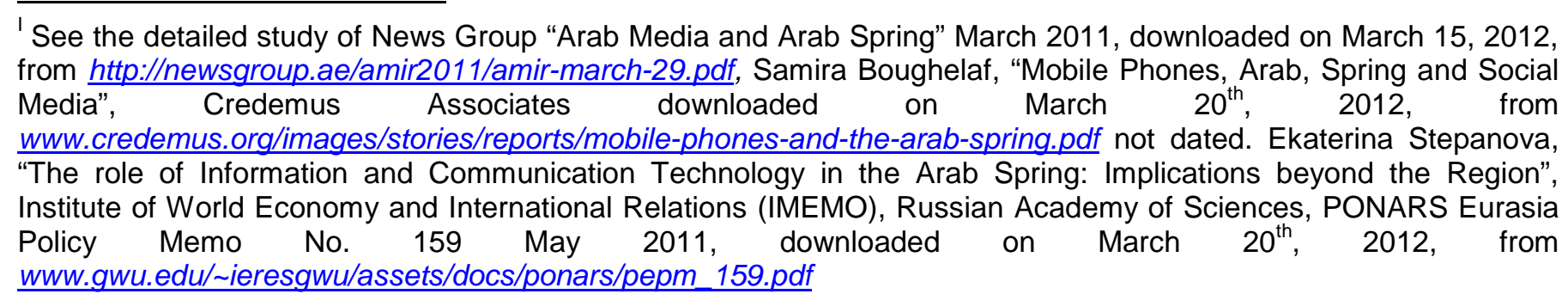

"The report, An Evaluation of Public Safety's Policy, Capacity and Resources Supporting Overseas Security Sector Reform, was published by Public Safety Canada in August 2011 (information obtained during an interview with the author, Dr. Ann M. Fitz-Gerald). 


\section{References}

Ablaye, R.T. (2005), "Code des Personnes et de la Famille: La preuve par l'amalgame", Tchad et Culture No. 238, June 2005, www.cefod.org/archives/spip.php?article601, accessed 14 March 2012.

Adisa, T. (2011), "FG Uncovers Boko Haram's Funding Secrets", Sunday Tribune, 24 July 2011, $\quad$ http://tribune.com.ng/sun/front-page-articles/4593-fg-uncovers-boko-harams-funding-secrets, accessed 20 March 2012.

Africa Works (2012), "Boko Haram's al-Qaeda links?", Africa Works website, $\quad$ http://africaworksgpz.com/2012/05/24/xan-rice-on-boko-haram/.

African Economic Outlook (undated), "Sudan", African Economic Outlook website, www.africaneconomicoutlook.org/en/countries/east-africa/sudan/, accessed 10 June 2012.

Afrique Expansion Magazine (2012), "Réunion à Alger sur la Lutte Antiterroriste au Sahel et en Afrique du Nord", Afrique Expansion Magazine, 11 September 2012, www.afriqueexpansion.com/depechesafp/5110-reunion-a-alger-sur-la-lutte-antiterroriste-au-sahel-et-en-afrique-du-nord.html

Agenzia Fides (2012) "Nigeria-Massacre d'Etudiants: Tous les indices portent à Boko Haram selon l'Archevêque de Jos ", Chretiente Info website, www.chretiente.info/201210051645/nigeria-massacredetudiants-tous-les-indices-portent-a-boko-haram-selon-larcheveque-de-jos/

Ahmed, B. (2012), "Video -Mali: Iyad Ag Ghaly, le Leader d'Ansar Dine se met en Scène", Jeune Afrique, 15 March 2012, http://www.jeuneafrique.com/Article/ARTJAWEB20120315171453/mali-att-djihadrebellion-touarequevideo-mali-iyad-ag-ghaly-le-leader-d-ansar-dine-se-met-en-scene.html, accessed 20 March 2012.

Aker, J.C. and I.M. Mbiti (2010), "Mobile Phones and Economic Development", Journal of Economic Perspectives, Vol. 24, No. 3, Summer 2010.

Alao, A. (2009), "Islamic Radicalisation and Violence in Nigeria: Country report", in T. Jaye (ed.) Militancy and Violence in West Africa: Reflecting on radicalisation, comparing contexts, and evaluating effectiveness of preventive policies, Conflict, Security and Development Group, available at www.securityanddevelopment.org/index.php?option=com content\&view=article\&id=62\&/temid=98.

Allen, C. (2006), God's Terrorists. The Wahhabi Cult and the Hidden Roots of Modern Jihad, Little Brown, London.

Ali, M. (2012), "Salafis vs Sufis: A simmering conflict in Sudan", Alakhbar English website, 14 March 2012, http://english.al-akhbar.com/content/salafis-vs-sufis-simmering-conflict-sudan, accessed 19 April 2012.

Ali, M. (1996), Ethnicity, Politics and Society in Northeast Africa: Conflict and social change, University Press of America, Lanham, Maryland.

Alkarouri, M. and M. Obeid (2003), Standard for Arabic Inclusion and Support, Revision 1.3, Arabeyes Project, http://projects.arabeyes.org/download/documents/distros/sais-en/sais-en.pdf.

AlSayyad, N. (2011), "The Fundamentalist City?", in N. AlSayyad and M. Massoumi (eds.) The Fundamentalist City? Religiosity and the Remaking of Urban Space, Routledge, New York. 
AlSayyid, N. and M. Massoumi, "The Future of the City: Religious fundamentalism in the city: Reflections on the Arab Spring", The Journal of International Affairs, Spring/Summer 2012, 65(2).

Anderson, J.W. (1999) "The Internet and Islam's New Interpreters', in D.F. Eickelman and J.W. Anderson (eds.), New Media in the Muslim World: The emerging public sphere, Indiana University Press, Bloomington.

Anderson, J.W. (2003), "New Media, New Publics: Reconfiguring the public sphere of Islam", Social Research 70(3): 887-906.

Anti-Defamation League, The (2012), "Boko Haram: The emerging jihadist threat in West Africa" The AntiDefamation League, www.adl.org/NR/exeres/0A52CE6C-05CA-455B-8C8A-2EECD82B2D69,DB7611A202CD-43AF-8147-649E26813571, frameless.htm, accessed 12 March 2012.

Anzar, U. (2003), Islamic Education: A brief history of Madrassas with comments on curricula and current pedagogical practices, draft report, available at www.uvm.edu/ envprog/madrassah/madrassahhistory.pdf, accessed 2 June 2012.

ATP (Agence Tchadienne de Presse) (2011), "Télécommunications: La fibre optique est devenue une réalité au Tchad", ATP website, www.infotchad.com/details.asp?item id=2729, accessed 10 June 2012.

Baldauf, S. (2012), "In Nigeria, Somalia and Afghanistan: What is a foreign fighter?", Christian Science Monitor, 27 February 2012, www.csmonitor.com/World/Africa/2012/0227/In-Nigeria-Somalia-andAfghanistan-what-is-a-foreign-fighter.

Bayart, J.F. (1986), "Civil Society in Africa: Reflections on the limits of power", in P. Chabal (ed.), Political Domination in Africa, Cambridge University Press, Cambridge.

Bayart, J.F. (1991), "Finishing with the Idea of the Third World: The concept of the political trajectory", in J. Manor (ed.), Rethinking Third World Politics Longman, London and New York.

Bayart, J.F. (2010), "Le Piège de la Lutte Antiterroriste en Afrique de l'Ouest", Sociétés Politiques Comparées, No.26, August 2010.

BBC (2011), "Sudan to Unleash Cyber Jihadists", BBC News website, 23 March 2011, www.bbc.co.uk/news/technology-12829808.

Ben Moussa, M. (2011), "The Use of the Internet by Islamic Social Movements in Collective Action: The case of justice and charity", Westminster Papers in Communications and Culture, Vol 8(2), October 2011, www.westminster.ac.uk/ data/assets/pdf file/0003/116616/001eWPCC Vol8issue2.pdf

Bevir, G. (2009), “Connecting Sudan," ITP.net website, 21 January 2009, www.itp.net/news/544237connecting-sudan.

Blair, D. (2012), "Al-Qaeda's Hand in Boko Haram's Deadly Nigerian Attacks" The Telegraph, 5 February 2012, www.telegraph.co.uk/news/worldnews/al-qaeda/9062825/Al-Qaedas-hand-in-Boko-Harams-deadlyNigerian-attacks.html.

Boudon, R. (1981), The Logic of Social Action: An introduction to sociological analysis, Routledge \& Kegan Paul, London. 
Bryson, S. (undated), "How Middle Eastern Funding Brings Conservative Islam to Ghana", NYULivewire website, http://journalism.nyu.edu/publishing/archives/livewire/global/how middle_east/, accessed 25 October 2012.

Budde.com (2012), "Chad- Telecom, Mobile and Internet", Budde.com website, www.budde.com.au/Research/Chad-Telecoms-Mobile-and-Internet.html, 28 February 2012 Bunt, G.R. (2003), Islam in the Digital Age: E-Jihad, online fatwas, and cyber Islamic environments, Pluto Press, London.

Butter, I. (2011), A Market Space Ethnography: Insecurity, communication, and identity in Chad, CERES Preliminary Research Design, ASC/University of Leiden, $\quad$ http://mobileafricarevisited.files.wordpress.com/2010/03/preliminary-research-design-ingebutter.pdf.

Chalk, F. and D. Kelton (2009), "Mass Atrocity Crimes in Darfur and the Response of Government of Sudan Media to International Pressure", in A. Grzyb (ed.), Crisis in Darfur, McGill-Queens University Press,

Montreal, http://migs.concordia.ca/documents/Chapter 5 Last copyeditofSudanRadiochapterforMcGillQu eensfromFrankChalk.doc.

Chichizola, J. (2006), "Al-Qaida Trouve un Soutien en Algérie", Le Figaro, 15 September 2006, $\quad$ www.lefigaro.fr/international/2006/09/15/01003-20060915ARTFIG90236al qaida trouve un soutien en algerie.php.

Coleman, J.S. (1990), Foundations of Social Theory, Belknap Press of Harvard University Press.

Council of the European Union (2007), "Partenariat stratégique Afrique-EU :Une stratégie commune Afrique-UE", Press release: 291 No 16344/07, 9 December, Council of the European Union, Lisbon.

Deegan, H. (1995), "Contemporary Islamic Influences in sub-Saharan Africa: An alternative development agenda", in E. Watkins (ed.), The Middle Eastern Environment, St Malo Press, Cambridge, available at www.netcomuk.co.uk/ jpap/deegan.htm, accessed 4 June, 2012.

DeLong-Bas, N.J. (2011) "The New Social Media and the Arab Spring", Focus On Essay, Oxford Islamic Studies Online website, www.oxfordislamicstudies.com/Public/focus/essay0611 social media.html, accessed 10 June 2012.

Diani, M. (2001), "Social Movement Networks: Virtual and real", in F. Webster (ed.), Culture and Politics in the Information Age, Routledge, New York.

Dickson, D. (2005), "Political Islam in Sub-Saharan Africa: The need for a new research and Diplomatic Agenda", Special Report 140, The United States Institute for Peace, Washington, DC, http://www.usip.org/files/resources/sr140.pdf.

Diebert, R. et al.(eds.) (2008), Access Denied: The practice and policy of global internet filtering, MIT Press, Cambridge, MA.

Djao, Y. (2006), "Islam from a sub-Saharan Africa Perspective" SA06: WEA Mission Commission Global Issues Summit June 18-24, 2006, Goudini Spa, South Africa, $\quad$ www.worldevangelicalalliance.com/commissions $/ \mathrm{mc} / \mathrm{mc}$ southafrica/resources/Djao\%20\%20Islam\%20from\%20an\%20African\%20perspective.pdf, accessed 8 March 2012. 
En Terre d'Islam (1937), “Arabization or Islamization?”, The Muslim World, 27(2), 1937, pp. 142-146.

Encyclopedia.com (undated), "Sudan",

website, $\underline{\text { http://www.encyclopedia.com/topic/Sudan.aspx }}$, accessed 29 October 2012.

Encyclopedia.com

European Commission (2008a), "Causal Factors of Radicalisation", Transnational Terrorism, Security and the Rule of Law series, Workpackage 4, European Commission, www.transnationalterrorism.eu/tekst/publications/Causal\%20Factors.pdf, accessed 13 May 2012.

European Commission (2008b), "Radicalisation, Recruitment and the EU Counter-Radicalisation Strategy", Transnational Terrorism, Security and the Rule of Law series, Deliverable 7, European Commission, www.transnationalterrorism.eu/tekst/publications/WP4\%20Del\%207.pdf.

European Commission (2008c), "The EU Counterradicalization Strategy: Evaluating EU policies concerning causes of radicalization", Transnational Terrorism, Security and the Rule of Law series, Workpackage $4, \quad$ Objective $\quad 6,6 u$ Epean Commission, www.transnationalterrorism.eu/tekst/publications/EU\%20Counterradicalization\%20Strategy. pdf.

Europol (2011),TE-SAT 2011: EU terrorism situation and trend report, Europol, www.europol.europa.eu/sites/default/files/publications/te-sat2011.pdf, accessed 3 June 2012.

L'Expression le Quotidien (2012), “Lutte anti-terroriste: appel à la création en Afrique d'un environnement législatif adéquat", L'Expression le Quotidien, 3 June 2012, $\quad$ http://www.lexpressiondz.com/linformation en continue/154724-lutte-antiterroriste\%3A-appel\%C3\%A0-la-cr\%C3\%A9ation-en-afrique-d\%26\%23039\%3Bun-environnement-I\%C3\%A9gislatif-

\%C2\%AB-ad\%C3\%A9quat-\%C2\%BB.html

Faris, R. and N. Villeneuve, (2008) "Measuring Global Internet Filtering", in R. Deibert, J. Palfrey, R. Rohozinski, and J. Zittrain (eds.), Access Denied: The practice and policy of global internet filtering, MIT Press, Cambridge, MA, http://opennet.net/sites/opennet.net/files/Deibert 02_Ch01_005-028.pdf, accessed 18 March 2012.

Farook, L. (2002), "Saudi Aid to Developing Countries Totals 75.5b", Saudi Arabian Information Resource website, www.saudinf.com/main/y4138.htm, accessed June 2012.

Gellar, S. (2006), "Religion and Democratization in Colonial and Post-Colonial Africa: Parallels in the evolution of religious and political governance structures", draft prepared for working conference Designing Constitutional Arrangements for Democratic Governance in Africa: Challenges and possiblities, 30-31 March 2006, Bloomington, Indiana, www.indiana.edu/ workshop/papers/gellar wrkconf.pdf

Glickman, H. (2011), "The Threat of Islamism in Sub-Saharan Africa: The case of Tanzania", Foreign Policy Research Institute E-Notes, April 2011, www.fpri.org/enotes/201104.glickman.islamismsubsaharanafrica.pdf, accessed on 15 March 2012.

Haynes, J. (1997), Democracy and Civil Society in the Third World: Politics and New Social Movements, Polity Press, Cambridge.

Hoff, R. (2005), "Dissident Watch: Arash Sigarchi”, Middle East Quarterly 12(4): 96. 
Hoffman, B. (2006), "The Use of the Internet by Islamic Extremists", Testimony presented to the House Permanent Select Committee on Intelligence on 4 2006, www.investigativeproject.org/documents/testimony/254.pdf, accessed 9 March 2012.

Howden, D. (2012), "Has the Arab Spring now spread to Sudan?", The Independent, 28 June 2012, $\quad$ http://www.independent.co.uk/news/world/africa/has-the-arab-spring-now-spread-to-sudan7893586.html.

Ibahrine, M. (2007), New Media and Neo-Islamism: New media's impact on the political culture in the Islamic world, VDM Verlag Dr. Mueller, Saarbrucken.

Ibrahim, R. (2012), "Muslim Brotherhood 'Democracy': Slapping, stabbing, and slaying for Sharia”, Middle East Forum website, 9 July 2012, www.meforum.org/3282/muslim-brotherhood-democracy.

Idris, J. (1997), The Process of Islamization, the Islamic Society of North America, Plainfield, Indiana. International Crisis Group (2005), "Understanding Islamism", Middle East/North Africa Report No. 37, International Crisis Group, merln.ndu.edu/archive/icg/Islamism2Mar05.pdf.

International Crisis Group (2008), "Chad: A new conflict resolution framework", Africa Report No. 144, International Crisis Group, www.crisisgroup.org/ /media/Files/africa/centralafrica/chad/Chad\%20A\%20New\%20Conflict\%20Resolution\%20Framework.pdf, accessed 10 June 2012.

International Crisis Group (2010), "Northern Nigeria: Background to conflict", Africa Report No. 168, International Crisis Group, www.crisisgroup.org/ /media/Files/africa/westafrica/nigeria/168\%20Northern\%20Nigeria\%20-\%20Background\%20to\%20Conflict.pdf, $\quad$ accessed 15 March 2012.

International Crisis Group (2012), "The Kenyan Military Intervention in Somalia", Africa Report No. 184, International Crisis Group, available at www.crisisgroup.org/en/regions/africa/horn-of-africa/kenya/184the-kenyan-military-intervention-in-somalia.aspx, accessed 20 October 2012.

International Press Institute (2005), "World Press Freedom Review - 2005 Sudan," $\quad$ http://www.freemedia.at/cms/ipi/freedom detail.html?country=/KW0001/KW0004/KW0104/, (accessed 4 August 2006).

Internet World Stats (2011), "Internet Usage Statistics for Africa", Internet World Stats Website, www.internetworldstats.com/stats1.htm, accessed 9 March 2012.

Ira, K. (2012), "France, US Step up Pressure for Military Intervention in Mali", 2 October 2012, World Socialist Website, www.wsws.org/articles/2012/oct2012/mali-o02.shtml.

Jalloh, A. (1997), "The Fula and Islamic Education in Freetown, Sierra Leone", American Journal of Islamic Social Sciences, 14(4), http://i-epistemology.net/attachments/499 V14N4\%20Winter\%2097\%20\%20Jalloh\%20-\%20The\%20Fula\%20and\%20Islamic\%20Education\%20in\%20Freetown\%20-

\%20Sierra\%20Leone.pdf, accessed 2 June 2012.

Jesús, C.E. (2004), "Radical Islam in the Maghreb", Orbis, Spring 2004, www.fpri.org/orbis/4802/jesus.islammaghreb.pdf.

Judy, M. (2011), "The Antithesis: Unveiling radical Islam's subversive methods directed against the democratic institution", Global Security Studies, Spring 2011, 2(2). 
Kaag, M. (2008), "Transnational Islamic NGOs in Chad: Islamic solidarity in the age of neoliberalism", Africa Today, Vol. 54, No.3, www.scribd.com/doc/21710685/Transnational-Islamic-NGOs-in-Chad-IslamicSolidarity-in-the-Age-of-Neoliberalism, accessed 21 March 2012.

Kamor, D. (2007), "The Trial of the Nigerian Taliban", Nigerian Village Square website, http://www.nigeriavillagesquare.com/articles/disu-kamor/the-trial-of-the-nigerian-taliban-5.html, accessed 15 March 2012.

Kane, O. (2003), Muslim Modernity in Postcolonial Nigeria: A study of the Society for the Removal of Innovation and Reinstatement of Tradition, Brill, Leiden.

Kort, A. (2005), "Dar al-Cyber Islam: Women, domestic violence, and the Islamic reformation on the world wide web", Journal of Muslim Minority Affairs 25(3): 363-83.

Lagu, J. (2006), Sudan: Odyssey through a state: From ruin to hope, MOB Center for Sudanese Studies, Omdurman Ahlia University, Omdurman.

Langman, L. and D. Morris (2002), "Islamic Terrorism: From retrenchment to ressentiment and beyond", in H.W. Kushner (ed.), Essential Readings on Political Terrorism: Analyses of problems and prospects for the $21^{\text {st }}$ Century, Gordian Knot, www. angelfire.com/or3/tss2/is/terror.html, accessed 15 March 2012.

LWJ (Long War Journal) (2012), "New Islamist Group Emerges in Nigeria, Vows to Defend all Muslims in Africa", Threat Matrix website, 4 June, 2012, www.longwarjournal.org/threatmatrix/archives/2012/06/new islamist group emerges in.php.

Lindow, M. (2007) "Islamic Universities Spread Through Africa", Chronicle of Higher Education, 53(44), 6 July 2007, http://meganlindow.wordpress.com/articles/islamic-universities-spread/.

Livingston, S. (2011), "Africa's Evolving Infosystems: A pathway to security and stability", Research Paper No. 2, Africa Center for Strategic Studies, downloaded on March 4, http://africacenter.org/wpcontent/uploads/2011/02/ARP2_02072011.pdf, accessed 4 March 2012.

Loimeir, R. (1996), Islamic Reform and Political Change In Northern Nigeria, Northwestern University Press, Evanston, Illinois.

Lyman, P.N. (2008), "The War on Terrorism in Africa", in J.W. Harbeson and D. Rothschild (eds.), Africa in World Politics: Reforming political order, Westview Press, www.cfr.org/content/thinktank/Lyman chapter Terrorism.pdf.

McAdam, D. (1982), Political Process and the Development of Black Insurgency, 1930-1970, University of Chicago Press, Chicago.

McCormack, D. (2005), "An African Vortex: Islamism in Sub-Saharan Africa", Occasional Papers Series No. 4, The Center for Security Policy, Washington, DC, www.offnews.info/downloads/Af Vortex.pdf, accessed 9 March 2012.

Marty, M.E. and R.S. Appleby (eds.) (1991), Fundamentalisms Observed, University of Chicago Press, Chicago.

Mongabay (1991), "Sudan: Radio and television", Mongabay website, www.mongabay.com/history/sudan/sudan-radio and television.html. 
Mustafa, D. and N.A. Abdul Razak (2012), "Islamic Development Bank, Foreign Aid and Economic Growth in Africa: A simultaneous equations model approach", International Journal of Economics and Finance, Vol. 4(6), www.ccsenet.org/journal/index.php/ijef/article/view/17411 , accessed 10 June, 2012.

Napoli, J.J. (2002), "Covering Islam in Egypt", Religion in the News, Spring 2002, Vol. 5(1), www.trincoll.edu/depts/csrpl/rinvol5no1/covering\%20lslam.htm.

Nnochiri, I. (2012), "Boko Haram: How we caught Nigerian Al-Qaeda leader - SSS", Vanguard, 4 April 2012, www.vanguardngr.com/2012/04/boko-haram-how-we-caught-nigerian-al-qaeda-leader-sss/.

Obala, L.M. (2012), South Sudan and Kenya: The relationships, Al Jazeera Center for Studies, http://studies.aljazeera.net/ResourceGallery/media/Documents/2012/3/29/201232915413854734 South\%20Sudan\%20and\%20Kenya.pdf, accessed 10 June 2012.

Omonobi, K.(2011), "Bombings: Military authorities arrest 950 Chadians, Nigeriens, Sudanese" Vanguard, October 11 2011, www.vanguardngr.com/2011/10/bombings-military-authorities-arrest-950-chadiansnigeriens-sudanese/, accessed 12 March 2011.

OpenNet Initiative (2009), Internet Filtering in Sudan, OpenNet Initiative http://opennet.net/sites/opennet.net/files/ONI Sudan 2009.pdf, accessed 9 June 2012.

Osaghae, E.E. (1999), "Exiting from the State in Nigeria”, African Journal of Political Science. (1999). Vol. $4(1)$, p. 83

http://archive.lib.msu.edu/DMC/African\%20Journals/pdfs/political\%20science/volume4n1/aips004001006. pdf, accessed 15 March 2012.

Ousman, A. (2004), "The Potential of Islamist Terrorist in Sub-Saharan Africa", International Journal of Politics, Culture and Society, Vol.18, Fall/Winter 2004.

Pérouse de Montclos, M.A. (2008), "Conversion to Islam and Modernity in Nigeria", Africa Today, Vol.54(4), p.75.

Prucha, N. (2010), "'Fursan al-Shahada, Part 8' Highlights Nigeria and Central Africa", Monitoring Jihad Online website, 19 November 2010, http://online-jihad.com/2010/11/19/\%E2\%80\%9Cfursan-al-shahadapart-8\%E2\%80\%9D-highlights-nigeria-and-central-africal.

Qudus Radio (undated), "Qudus Radio: Voice of Islam" Qudus Radio website, www.taawunuonline.net/qudusradio/en/?id=aboutus, accessed 9 June 2012.

Rabasa, A. (2009), Radical Islam in East Africa, prepared for the United States Air Force, Rand Project Air Force.

Rao, M. (2011), Mobile Africa Report 2011: Regional hubs of excellence and innovation, Mobile Monday, www.mobilemonday.net/reports/MobileAfrica 2011.pdf, accessed 8 March 2011.

Rheingold, H. (2002), Smart Mobs: The next social revolution, Perseus, Cambridge, MA.

Robin, B. (2012), "Understanding the Muslim Brotherhood", Footnotes, June 2012, Foreign Policy Research Institute www.fpri.org/footnotes/1708.201206.rubin.muslim-brotherhood.pdf. 
Rogio, B. (2012), "Suicide Bomber Kills 15 at Nigerian Church", 3 June 2012, Threat Matrix, A blog of the Long War Journal, matrix/archives/2012/06/suicide_bomber kills_15 at nig.php

www.longwarjournal.org/threat-

Schmidt, V.A. (2008), "Discursive Institutionalism: The explanatory power of ideas and discourse", Annual Review of Political Science, 11:303-326.

Scholarships for Development (2012), "IDB Scholarships for Muslims in Africa and Asia", Scholarships for Development website, www.scholars4dev.com/3729/idb-scholarships-for-muslims/, accessed 12 March 2012.

Servold, G. (2003), "The Muslim Brotherhood and Islamic Radicalism", in B.R. Schneider and J.M. Post (eds.), Know thy Enemy: Profiles of Adversary Leaders and their Strategic Cultures, www.au.af.mil/au/awc/awcgate/cpc-pubs/know thy enemy/servold.pdf, accessed October 2010.

SHAFAQNA (Shia International News Association) (2012), "In Nigeria, Islamic Leaders Call on Boko Haram to End Violence", 31 July 2012, www.shafaqna.com/english/component/k2/item/5346-in-nigeriaislamic-leaders-call-on-boko-haram-to-end-violence.html.

Shiklam, J. (2007), "Nigeria: Sultan - We Must Counter Christians", Daily Champion, 3 July 2007.

State University.com (undated), "Sudan-Educational System - Overview", State University Education Encyclopedia website, http://education.stateuniversity.com/pages/1432/Sudan-EDUCATIONAL-SYSTEMOVERVIEW.html, accessed 22 October 2012.

Terdman, M. (2007a), Islam in Africa Newsletter, Vol. 2(3), July 2003, Global Research in International Affairs (GLORIA) Center, www.e-prism.org/images/Islam in Africa Newsletter - No3 vol 2 July 2007.pdf.

Terdman, M. (2007b), "Factors Facilitating the Rise of Radicalism and Terrorism in Sub-Saharan Africa", African Occasional Papers, Vol 1(1), GLORIA Center, Intelligence and Terrorism Information Center at the Center for Special Studies, info.org.il/malam_multimedia/English/eng_n/html/prism0307.htm.

Tibi, B. (1998), The Challenge of Fundamentalism: Political Islam and the new world disorder, University of California Press, Berkeley.

US Africa Command (2011), "About US Africa Command", US Africa Command website, http://www. africom.mil/AfricomFAQs.asp.

US Department of State (2008), "Country Reports on Human Rights Practices: Sudan", Bureau of Democracy, Human Rights, and Labor website, www.state.gov/g/drl/rls/hrrpt/2007/100506.htm.

US Department of State (2010), "Country Reports on Human Rights Practices: Chad", Bureau of Democracy, Human Rights, and Labor website, www.state.gov/documents/organization/171607.pdf

US Department of State (2011), "2011 Investment Climate Statement - Chad", Bureau of Economic, Energy and Business Affairs website, www.state.gov/e/eb/rls/othr/ics/2011/157256.htm.

Voice of the Cape, The (2012), "Saudi Scholarship for Women", Voice of the Cape, 16 March 2012, $\quad$ www.vocfm.co.za/index.php?option=com k2\&view=item\&id=3773:2012-03-17-03-2222\&ltemid=131. 
Warburg, G.R. (2006), The Muslim Brotherhood in Sudan: From reform to radicalism, GLORIA Center, Islam in Africa Research Project, http://www.e-prism.org/images/Muslim BROTHERS.PRISM.pdf, accessed 15 March 2012.

White House, the (2012), U.S. Strategy Towards Sub-Saharan Africa, June 2012, The White House, Washington, DC, www.whitehouse.gov/sites/default/files/docs/africa strategy 2.pdf.

Wikipedia (undated a), "Islamism", Wikipedia website, http://en.wikipedia.org/wiki/Islamism\#cite note-0, accessed 23 October 2012.

Wikipedia (undated b), "Hawala", Wikipedia website, http://en.wikipedia.org/wiki/Hawala, accessed 20 March 2012.

Wikipedia (undated c), "List of Mobile Network Operators of the Middle East and Africa", Wikipedia website, http://en.wikipedia.org/wiki/List of mobile_network operators of the Middle_East and Africa\#Chad.

Wikipedia (undated d), "Chad", Wikipedia website http://en.wikipedia.org/wiki/Chad

Wiktorowicz, Q. (2001), "The New Global Threat: Transnational Salafis and jihad", Middle East Policy, Vol.8(4), pp. 18-38.

Windeck, F. (2010), "Political Communication in Sub-Saharan Africa and the Role of New Media", Konrad Adenauer Stiftung International Reports 6/2010, http://www.kas.de/wf/doc/kas 19703-544-230.pdf?100526134006, accessed 12 March, 2012.

Worldmark Encyclopedia of Nations (2007), "Sudan", online encyclopedia, available at www.encyclopedia.com/topic/Sudan.aspx, accessed 12 November 2012.

Yazid, F.A. (2012) "Cotton Returns as Strategic Crop", Sudan News Agency website, 3 April 2012, http://sudanow.info/en/en-analysis.php?ID=524\&show=SC, accessed 10 June 2012.

Zeidane, A. (2004), "Tchad: Blocage islamiste au code de la famille laïc" Syfia Info Agence de presse website, 5 October 2004, www.syfia.info/index.php5?view=articles\&action=voir\&idArticle=3882, accessed 10 June 2012.

Zoomtchad (2010), "19 Ans de Pouvoir ou Comment le Régime de Deby a Favorisé l'émergence d'un Islamisme Fondamental au Tchad", Zoom sur le Tchad website, 28 March 2010, www.zoomtchad.com/index.php?option=com content\&view=article\&id=72:19-ans-de-pouvoir-oucomment-le-regime-deby-a-favorise-lemergence-dun-islamisme-fondamental-au-tchad-demain-lesconflits-\&catid=4:zoom-sur\&ltemid=5, accessed 21 March 2012. 


\section{Annex A: Internet use in sub-Saharan Africa}

\begin{tabular}{|c|c|c|c|c|c|c|}
\hline COUNTRY & $\begin{array}{l}\text { Population } \\
\text { (2011 } \\
\text { estimate) }\end{array}$ & $\begin{array}{l}\text { Internet } \\
\text { users } \\
\text { Dec } 2000\end{array}$ & $\begin{array}{l}\text { Internet } \\
\text { users } \\
31^{\text {st }} \text { Dec } \\
2011\end{array}$ & $\begin{array}{l}\text { Penetration } \\
2011 \\
\text { (\% } \\
\text { population) }\end{array}$ & $\begin{array}{l}\text { Users } 2011 \\
\% \text { Africa }\end{array}$ & $\begin{array}{c}\text { Facebook } \\
\text { accounts } \\
\text { (no.) } 31^{\text {st }} \\
\text { Dec } 2011\end{array}$ \\
\hline $\begin{array}{l}\text { Burkina- } \\
\text { Faso }\end{array}$ & 16751455 & 10000 & 230000 & $1.4 \%$ & $0.2 \%$ & 95930 \\
\hline Cameroon & 19711291 & 20000 & 783956 & $4.0 \%$ & $0.6 \%$ & 467340 \\
\hline CAR & 4950027 & 1500 & 123800 & 2.5 & $0.1 \%$ & 123800 \\
\hline Chad & 10758945 & 1000 & 190863 & $1.8 \%$ & $0.1 \%$ & 38000 \\
\hline Côte d'Ivoire & 21504162 & 40000 & 968000 & $4.5 \%$ & $0.7 \%$ & $\mathrm{n} / \mathrm{a}$ \\
\hline Djibouti & 757074 & 1400 & 61320 & $8.1 \%$ & $0.0 \%$ & 51240 \\
\hline Eritrea & 5939484 & 5000 & 283699 & $4.8 \%$ & $0.2 \%$ & 19180 \\
\hline Ethiopia & 90873739 & 10000 & 622122 & $0.7 \%$ & $0.4 \%$ & 472460 \\
\hline Ghana & 24791073 & 30000 & 2085501 & $8.4 \%$ & $1.5 \%$ & 1146560 \\
\hline Mali & 14159904 & 18800 & 414985 & $2.9 \%$ & $0.3 \%$ & 132720 \\
\hline Niger & 16468886 & 5000 & 128749 & $0.8 \%$ & $0.1 \%$ & 44580 \\
\hline Nigeria & 155215573 & 200000 & 45039711 & $29.0 \%$ & $32.2 \%$ & 4369740 \\
\hline Senegal & 12643799 & 40000 & 1989396 & $15.7 \%$ & $1.4 \%$ & 620260 \\
\hline Somalia & 9925640 & 200 & 106600 & $1.1 \%$ & $0.1 \%$ & 55140 \\
\hline Sudan & 45047502 & 30000 & 4200000 & $9.3 \%$ & $3.0 \%$ & $\mathrm{n} / \mathrm{a}$ \\
\hline
\end{tabular}

Source: The statistics on these 15 countries are drawn from Internet World Stats: www.internetworldstats.com/stats1.htm 


\begin{tabular}{|l|l|l|l|l|l|l|}
\hline \multicolumn{7}{|l|}{ Table A.2. How Internet use in Africa compares to the rest of the world } \\
\hline $\begin{array}{l}\text { AFRICA } \\
\text { REGION }\end{array}$ & $\begin{array}{l}\text { Population } \\
(2011 \\
\text { estimate) }\end{array}$ & $\begin{array}{l}\% \text { of } \\
\text { world } \\
\text { popn }\end{array}$ & $\begin{array}{l}\text { Internet users } \\
31^{\text {st }} \\
2011\end{array}$ & $\begin{array}{l}\text { Penetration } \\
(\% \\
\text { population) }\end{array}$ & $\begin{array}{l}\text { Users } \\
(\% \\
\text { world) }\end{array}$ & $\begin{array}{l}\text { Facebook } \\
\text { accounts (no.) } \\
31^{\text {st }} \\
2011\end{array}$ \\
\hline $\begin{array}{l}\text { December } \\
\text { Africa }\end{array}$ & 1037524058 & $15.8 \%$ & 139875242 & $13.5 \%$ & $6.2 \%$ & 37739380 \\
\hline $\begin{array}{l}\text { Rest of } \\
\text { world }\end{array}$ & 5892531096 & $85.0 \%$ & 2127358500 & $36.1 \%$ & $93.8 \%$ & 761352780 \\
\hline $\begin{array}{l}\text { World } \\
\text { total }\end{array}$ & 6930055154 & $100.0 \%$ & 2267233742 & $32.7 \%$ & $100.0 \%$ & 799092160 \\
\hline
\end{tabular}

Notes: Internet usage and population statistics for Africa are for December 31, 2011. Population numbers are based on figures from the US Census Bureau. The Internet usage numbers come mainly from data published by WWW, ITU, the Nielsen Company, Facebook, and other trustworthy sources (downloaded on March 9th, 2012).

Source: Internet World Stats: www.internetworldstats.com/stats1.htm 
